\title{
Whose right to manage? Distribution of property rights affects equity and power dynamics in comanagement
}

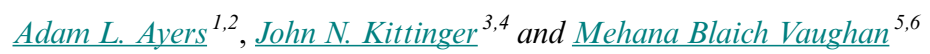

\begin{abstract}
Rights-based management approaches are being increasingly applied to global fisheries as an alternative to deficiencies associated with centralized or top-down management. In fisheries, these approaches may include a diversity of methods such as catch shares, territorial user rights for fishing, individual transferable quotas, fisheries concessions, cooperatives, and comanagement. Many of these approaches are being implemented in small-scale fisheries contexts, without full consideration of how the legacy of previous governing institutions or tenure arrangements may affect implementation. Likewise, few case studies examine whether rights-based management approaches are appropriate for given contexts, examine how they fit within a nested administrative hierarchy, or describe their shared property rights components in practice. These knowledge gaps may obscure key stewardship incentives, veil existing power relations, and constrain opportunities for different management models while also prolonging or preventing governance transformations. We illustrate the importance of these factors through a case study of institutional change in coral reef fisheries in Hawai i. We use institutional analysis to examine coral reef fisheries management across two time periods: historical marine tenure in the Hawaiian Kingdom (1810-1893) and under contemporary centralized management (1982-2018). We then compared these management regimes to emerging comanagement in Hawai i (1994-2018). Our analysis reveals that few rights are actually devolved to communities seeking to implement comanagement. We also highlight considerable administrative complexity and variability within historical marine tenure regimes. We conclude by considering several issues relevant to the performance of rights-based approaches such as comanagement, including devolution of property rights to the local level, matching administrative and social-ecological complexity, the importance of historical context and narratives in shaping solutions, and the perceived legitimacy of governance arrangements.
\end{abstract}

Key Words: collective action; common-pool resources; coral reef fisheries; coral reefs; fisheries management; governance; institutional analysis; legitimacy; property rights; rights-based management; social justice; transformations

\section{INTRODUCTION}

Marine fisheries provide an estimated $17 \%$ of human dietary protein globally but account for $>50 \%$ of coastal and island areas (Food and Agriculture Organization 2016). Despite the importance of marine fisheries for food, protein, and micronutrients, more than half of fisheries are unsustainable (Rosenberg et al. 2018), and investment in the sector has declined significantly (Blasiak and Wabnitz 2018). From a broad perspective, rights-based approaches entail placing organizational or distributional rights into the hands of fishers (T. Yandle and M. T. Imperial, unpublished manuscript). However, these rights can vary significantly with regard to their form and function and may include different policy approaches such as catch shares, territorial user rights for fishing, individual transferable quotas, fisheries concessions, cooperatives, and comanagement. In practice, rights-based approaches may involve limited entry, defined spatial rights, or dedicated resource allocations (Yandle 2006, 2007). Common among all rights-based approaches are ceded rights to confer stewardship incentives that encourage sustainable harvesting behavior.

Although not widely characterized as a conventional rights-based approach, comanagement describes a variety of institutional arrangements that devolve authority and rights to communities or resource users, particularly in indigenous contexts such as
Aotearoa (New Zealand), Canada, and Alaska (USA; Pinkerton 1992, Ginter 1995, Taiepa et al. 1997, Davis and Jentoft 2001, Yandle 2007, Carothers 2011, Capistrano and Charles 2012). Comanagement has gained significant traction worldwide as one of the most promising solutions to resource decline, regulatory compliance, and feasibility (Gutiérrez et al. 2011). Comanagement encompasses a wide array of approaches but typically includes shared management authority among user groups or communities and governmental agencies (Sen and Nielsen 1996, Berkes 2010). In practice, shared management authority can take many different forms, and comanagement arrangements may exhibit significant diversity in the distributions of specific property rights among comanaging groups (Yandle 2007). Together, the following property rights components provide a common framework to analyze and compare fisheries management regimes. These components include: access (the right to enter a resource area), withdrawal (the right to harvest resource units), exclusion (the right to exclude others from entering a resource area), management (the right to make and enforce rules regarding access, withdrawal, and exclusion), and alienation (the right to sell, lease, or transfer any of the above rights; Schlager and Ostrom 1992). There are other dimensions that could also be used to analyze property rights components further such as duration (how long an individual has possessed a right) and quality of title (Scott 1988), as well as other complex

\footnotetext{
${ }^{1}$ Department of Urban and Regional Planning, University of Hawai'i at Mānoa, ${ }^{2}$ Joint Institute of Marine and Atmospheric Research, ${ }^{3}$ Conservation International, Center for Oceans, Honolulu, Hawaii, ${ }^{4}$ Julie Ann Wrigley Global Institute of Sustainability, Arizona State University, Tempe, Arizona, USA, ${ }^{5}$ Department of Natural Resources and Environmental Management, University of Hawai'i at Mānoa, ${ }^{6}$ Hawai'i Sea Grant College Program and Hui 'Āina Momona
} 
spatial and temporal considerations, particularly in open ocean fisheries (Wilson 2006, Yandle 2007). Here, we rely on Schlager and Ostrom's (1992) framework for clear comparative analysis.

Devolution of these various property rights components to the local level may vary geographically based on a country's legal system or by way of the informal institutions that may mediate their implementation. Institutions can be broadly defined as "enduring regularities of human action in situations structured by rules, norms, and shared strategies, as well as the physical world" (Crawford and Ostrom 1995:582) and may include formal rules such as laws or rules-in-use that govern a resource area (McGinnis 2011) such as a geographically bounded coral reef ecosystem. Rules-in-use or de jure rules may include informal norms or a shared code of conduct among fishers in a given resource area that outlines where, when, and how to harvest marine resources. Problems may arise in resource areas due to a variety of social, cultural, ecological, political, or economic variables, different configurations of which may compound their effects (Acheson 2006). However, the primary intervention available to address resource decline and social dilemmas is through governance, or institutional arrangements, that define rules (Imperial 1999). Governance for coral reef fisheries may include various management tools, including spatial management (e.g., marine protected areas), gear restrictions, output controls, managing access, and more. From an institutional perspective, these tools may be implemented by a centralized government, resource appropriators at the local level, a private entity, or through hybrid management approaches such as comanagement (Yandle 2003, Imperial and Yandle 2005). However, problems may arise when rules are not understood because of the inexactness of written language (Ostrom 1980), when resource users do not perceive rules to be fair or legitimate (Jentoft 2000, Nielsen 2003), or when rules do not address known common-pool resource dilemmas (Ostrom 1990, Cox et al. 2010, Baggio et al. 2016).

Elinor Ostrom and her colleagues at the Workshop in Political Theory and Policy Analysis at Indiana University recognized the inherent social complexity of resource systems and developed the institutional analysis and design (IAD) framework to help better understand, compare, and diagnose interactions and outcomes (Kiser and Ostrom 1982). The IAD framework introduced the concept of a focal action situation whereby individuals or groups of individuals interact, resulting in variable outcomes. In the earliest iterations of the framework, interactions were affected by biophysical conditions, community attributes, and rules (Ostrom 2005). These interactions may occur at four nested levels of decision making, including meta-constitutional, constitutional, collective choice, and operational levels, the latter of which is the only decision-making arena in which rules directly affect resources (Kiser and Ostrom 2000). As a concept, the action situation provides an opportunity to categorize a common set of variables such as which individuals or organizations are involved, their positions of authority, the range of potential actions and related outcomes, the amount of control they have over decisions, the information available to those involved, the costs and benefits of various actions and outcomes, and common evaluative criteria to measure their performance (Ostrom et al. 1993, Ostrom 2011). The action arena concept also allowed Ostrom and other researchers to test combinations of different variables iteratively through game theory in laboratory settings, which could be compared or contrasted with empirical evidence from real commons dilemmas (Ostrom et al. 1994). Subsequent revisions of the IAD framework allowed for more nuanced attention to social, economic, political, and ecological variables, interactions, and feedbacks (Ostrom 2007, 2009, McGinnis and Ostrom 2014). In sum, the IAD framework provides a common criterion that scholars can use to assess and compare institutional arrangements and property rights regimes through institutional analysis. Institutional analysis examines how institutions and surrounding contexts at different levels affect incentives, decision making, social-ecological systems interactions, program implementation, and outcomes at different scales (Ostrom 2005, McGinnis and Ostrom 2014).

Despite the promise of comanagement, there are high transaction costs associated with transitioning from a governance arrangement in which government holds most of the property rights in a centralized bureaucracy to an approach in which rights to develop operational rules are shared with communities or user groups (Ayers et al. 2017). Common issues identified by scholars with the design and implementation of rights-based approaches in comanagement include a lack of equity in collective choice decision-making processes (Yandle 2003), unequal power relations (Taiepa et al. 1997, Nadasdy 2003), a disregard for different worldviews or refusal to accept different data types (Diver 2012), rent seeking by stakeholders (Imperial and Yandle 2005), and elite capture of benefits (MacNeil and Cinner 2013). Governance transitions are rarely win-win, and new institutional arrangements are often constrained by past interactions, historical events, and previous successes or failures.

As more fisheries systems transition to comanagement arrangements, there is a need to assess the key factors that are related to social and ecological success, as well as the key factors associated with suboptimal or deleterious outcomes, particularly in areas where communities are dependent on resources (Ostrom 2009, Cinner et al. 2012; T. Yandle and M. T. Imperial, unpublished manuscript). As a diagnostic tool, institutional analysis can provide a common framework to describe, analyze, and compare fisheries comanagement institutions (Imperial and Yandle 2005, McGinnis 2011). In addition, a historical examination of changes in property rights over time may be valuable in identifying turning points (Baumgartner and Jones 2009) and trajectories or pathways that shaped contemporary governing institutions (Liebowitz and Margolis 1995). Historical analyses can facilitate greater understanding of current constraints and dynamics associated with the design of present and future governance regimes (Howlett and Rayner 2006).

Here, we conduct an institutional analysis to analyze Hawai'i's unique history of marine tenure, its transition to centralized management, and its recent experience with comanagement. This research is guided by the following two research questions. (1) How have the rules hierarchy and property rights for small-scale fisheries in Hawai i changed over time? (2) Given historical change in marine tenure and institutional arrangements, what limitations and opportunities exist for incorporating rights-based approaches in comanagement? We first present a brief history of historical events in Hawai $i$ that have shaped institutional changes in fisheries management. Next, we analyze administrative and 
Table 1. Data types, sources, citations, examples, and analytical tools used to examine changes in property rights and administrative decision making over three time periods and governance regimes in Hawai i coral reef fisheries. $N=16$.

\begin{tabular}{llll}
\hline \hline Data type & Data source & Citation & Data analysis \\
\hline Archival or historical & $\begin{array}{l}\text { Indigenous Hawaiian mo'olelo (stories or } \\
\text { histories) }\end{array}$ & Malo (1951) & Institutional analysis \\
& $\begin{array}{l}\text { Oral history } \\
\text { Archaeological and historical }\end{array}$ & Titcomb (1972), Maly and Maly (2003) \\
& anthropological studies & Kirch and Sahlins (1994), Kirch (2007, \\
& Marine historical ecology & $2010)$ & Kittinger et al. (2011) \\
& Hawaiian historical research & Beamer (2014), Gonschor and Beamer & \\
& & (2014) & Legal analysis \\
Published literature & Published manuscript & Kittinger et al. (2011), Friedlander et al. & Policy analysis \\
& & (2013) & Institutional analysis \\
Technical report & Policy briefing & Kittinger et al. (2012) & Legal analysis, institutional \\
& Legislative report & Macki (1954) (1991), Van Dyke (2008), & analysis \\
\hline Legal analysis or reference & Legal handbook & Forman and Serrano (2012) & \\
& & &
\end{tabular}

property rights differences between two time periods: the Hawaiian Kingdom (1810-1893) and contemporary centralized management (1982-2018). We then assess the major issues surrounding comanagement in Hawai' i (1994-2018) and conclude with the implications of our findings for the design of rights-based governance arrangements in Hawai $i$ and elsewhere.

\section{METHODS}

To assess the effect of major changes in property rights and administrative decision making for Hawai i coral reef fisheries, we identified two distinct time periods with three markedly different governance regimes in Hawai' $i$ coral reef fisheries. The governance regimes being compared included: (1) historical marine tenure during the period of Hawaiian self-governance (1810-1893), (2) contemporary centralized or bureaucracy-based management (1982-2018), and (3) contemporary comanagement (1994-2018). We recognize at the outset that these broad categories gloss over nuanced shifts in how governance regimes changed in the Hawaiian archipelago, which are attributed to a range of social, economic, political, and cultural factors (Kame'eleihiwa 1992, Preza 2009, Beamer 2014).

We used a comparative approach because: (1) the analysis was conducted retrospectively; (2) the efficacy of the governance regimes was difficult to definitively disentangle from other confounding causal mechanisms; (3) it allowed us to make use of multiple, diverse data sources; and (4) it enabled us to examine, build, and refine theoretical constructs and not generalize to populations or make predictions (Agranoff and Radin 1991). We used multiple data sources and analytical tools to examine changes in property rights and administrative decision making (Table 1).

Data sources gathered and analyzed for this research include archival and historical accounts of historical marine tenure regimes collected by indigenous Hawaiian scholars (e.g., Malo 1951, Kamakau 1976, 'İ'ì 1993, Kahā'ulelio and Nogelmeier 2006), oral histories collected from knowledgeable $k \bar{u}$ puna (elders; e.g., Titcomb 1972, Maly and Maly 2003), archaeological and historical anthropological studies (e.g., Kirch 2010), historical ecological analysis (e.g., Kittinger et al. 2011), and Hawaiian historical research (e.g., Beamer 2014, Gonschor and Beamer
2014). A comprehensive list of historical sources accessed in this research can be found in other works that the coauthors were either directly involved in, or know intimately, including Kittinger (2010), Kittinger et al. (2011), Vaughan (2012), and Friedlander et al. (2013). To examine what is possible under the United States and Hawaiian laws, our research drew upon a legal analysis of native Hawaiian resource rights (MacKenzie 1991, Van Dyke 2008, Forman and Serrano 2012), a policy analysis of contemporary fisheries policy instruments in Hawai i (Kittinger et al. 2012), and rules and management plans for the only two comanagement areas that have been actively managed since the early 2000s in Hawai'i (Hui Malama O Mo'omomi 1995, Community Members of Hā‘ena et al. 2011).

We systematically examined the historical and contemporary texts for descriptions of institutions, the political and administrative hierarchy of decisions made to govern natural resources such as coral reef fisheries, and noted periods of governance transitions. We provided a summary of some of the different data sources and how they were thematically coded (Miles and Huberman 1994) for institutional analysis (Table 2). To increase the accuracy of our research findings, we crosschecked published historical accounts of tenure and property rights arrangements. The findings were further shared with noted scholars in this subject area for expert review to increase robustness.

The themes emerging from the diverse historical and contemporary archival data sources were analyzed using the IAD framework (McGinnis 2011) and a property rights framework (Schlager and Ostrom 1992). The IAD framework is an analytical tool that can be used to examine how institutions (rules) and other variables influence decision making at multiple levels. We used the IAD framework primarily to examine the decision-making authority present at multiple different levels: meta-constitutional, constitutional, collective choice, and operational levels. The IAD framework can be useful for examining fisheries governance arrangements and other commons situations because of emphasis on contextual factors, interactions that occur at different levels, and evaluative criteria (Imperial and Yandle 2005). We also used a property rights framework developed by Schlager and Ostrom 
Table 2. Examples of data sources and coding used to inform institutional analysis.

\begin{tabular}{l}
\hline Data statement \\
"Traditional Hawaiian political and economic life was organized around a formal, nested \\
hierarchy of units" \\
"The corporate body of the government was the whole nation, including the common \\
people and chiefs under the king" \\
"A mō'î who consolidated rule with the support of the 'aha ali'i would create centralized \\
governance, enabling palena to be established through that central authority"
\end{tabular}

governance, enabling palena to be established through that central authority"

"Following the death of the previous mō'ī, all lands awarded in the previous reign would revert to the new mō's, who would then redistribute the lands with the aid of an advisor, the kālaimoku"

"The kapu, or a prohibition system, allowed ali $i$ or chiefs, and the konohiki that supervised the hoa' àina, to reinforce and coordinate conservation practices. Fishing kapu restricted and prohibited fishing practices according to season, areas, or type of harvest marine resource"

"Resource protection measures were apparently robust due to incentives and draconian punishments for rule breakers and the efficacy of these institutions is evidenced by ethnographic information, anecdotal accounts by early observers and analysis of archaeological deposits"

"Any changes to administrative rules in the State of Hawai'i must comply with the Hawai'i Administrative Procedure Act, also known as the Chapter 91 administrative rulemaking process. This rulemaking process is intended to enable transparency in public policy. Administrative rules changes must also comply with other applicable laws, including the Small Business Regulatory Flexibility Act and Administrative Directive No. 09-01, which requires the Governor's approval to schedule public hearings on rule changes"

"...none of the public lands in Hawai'i (whether ceded or not) can be sold or transferred without a two-thirds vote by both chambers of our Legislature"

"BLNR will vote to adopt, revise or reject the proposed rule change at a board meeting. With BLNR approval, the DAR sends the rule package to the Attorney General for final approval, after which the Chair sends it to the Governor for signing into law. If BLNR recommends substantive rule changes, the group may need to re-vet them with the community before DAR requests another public hearing. If a small businesses impact statement was prepared, DAR sends a public hearing summary to the SBRRB, who send a recommendation to the Governor to approve or reject the rules"

"The DLNR's Division of Conservation and Resources Enforcement (DOCARE) is responsible for the enforcement of all state laws, rules and regulations related to natural resources conservation and protection"

"Take up to two he'e per day, and possess up to two he'e at any one time, provided that he'e may only be taken by hand-harvest or with the use of a stick no longer than two feet in length"

"Whilst CBSFAs provide a mechanism for community groups to recommend regulations and carry out management activities to support the State's management of nearshore marine resources (i.e. monitoring, outreach), the DLNR must determine the balance of interests and actions necessary to manage marine resources and protect traditional and customary fishing practices, and is ultimately responsible for designating and adopting and enforcing rules for CBSFAs. DLNR relies on the best available information to inform its management decisions, and CBSFAs promote informed management decisions through the integration of the best available western and indigenous observational science and knowledge systems. In addition, CBSFA designations or rules must be adopted in accordance with HRS Chapter 91, which prescribes administrative rule-making procedures for state agencies to ensure due process and consideration of all public interests"

Source

Source

Kirch and Sahlins

(1992) as cited in

Kirch (2010:47)

Malo (1951)

Beamer (2014:35)

Beamer (2014:45)

Higuchi (2008:197)
Kittinger et al. (2012:4)

Van Dyke (2010)

\section{Zanre (2014:10)}

Zanre $(2014: 10)$

\section{Coding for institutional analysis \\ Nested hierarchy of decision making during the Hawaiian Kingdom}

Meta-constitutional level and the nested hierarchy of decision making during the Hawaiian Kingdom Meta-constitutional and constitutional levels of decision making during the Hawaiian Kingdom

Political redistribution of lands following the death of the mōi 1 , which could oust konohiki, and ali i at various levels

Hawaiian Kingdom management authority; operational-level rules; local-level management rights

Enforcement of rules and success of Hawaiian Kingdom governance

Complex collective choice rulemaking process; public participation process for comanagement

Restriction of alienation rights under centralized management and comanagement Collective choice level of decision making for operational-level rules under centralized management and comanagement

Division of Aquatic Resources (2016:20)

Division of Aquatic Resources (2016)

Division of Aquatic Resources (2016:7) management and comanagement
Enforcement of coral reef fishing regulations for both centralized Operational rules for Hāena community-based subsistence fishing area (CBSFA)

Hierarchy of decision making present under centralized management and comanagement; management rights; limitations of authority under CBSFAs
(1992) to examine which entity shares or retains five property rights components: access, withdrawal, exclusion, management, and alienation. This property rights framework has been used in other fisheries settings to uncover and compare governance arrangements (Schlager and Ostrom 1999; T. Yandle and M. T. Imperial, unpublished manuscript). Although the IAD framework and a property rights lens may not be useful in examining all resource interactions, e.g., how users may benefit from resources 
(Ribot and Peluso 2003) or when resource users exhibit a high discount rate (Bromley 1991), they can be used to diagram, analyze, and elucidate the diversity of institutional arrangements present in the context of marine tenure and governance regimes.

\section{BACKGROUND}

We next provide a short synthesis of major historical events that have affected coral reef fisheries management in Hawai i. We note at the outset that this synthesis focuses narrowly on a set of key historical events that had particular relevance for coral reef fisheries management. Because this summary is at the macro level, by necessity it neglects many important nuances of history. Interested readers can explore this history in greater detail through existing works by scholars that have focused their attention on historical marine tenure systems in Hawai' $i$ (Kittinger 2010, Kittinger et al. 2011, Vaughan 2012, 2018, Friedlander et al. 2013), as well as a range of scholarly publications that focus on aspects of Hawaiian history with relevance to natural resource use and management (Kame'eleihiwa 1992, Kirch 2007, 2010, Van Dyke 2008, Beamer 2014, Gonschor and Beamer 2014).

\section{Marine tenure in pre-contact Hawai i}

Hawai' $i$ is one of the last places on earth to be colonized by humans, as part of the expansion of eastern Polynesia (Wilmshurst et al. 2011). Although historical ecological evidence points to exploitation of coral reef resources after first contact, coral reef resources exhibited recovery after AD 1400, likely because of the further development of resource management systems as well as the intensification of land-based food production systems (Vitousek et al. 2004, Kittinger et al. 2011). The period of resource recovery in the pre Western contact era is associated with the rise of a complex hierarchical system of land and marine tenure known colloquially as the ahupua' $a$ system (Beamer 2014). Ahupua'a can be defined as a "culturally appropriate, ecologically aligned, and place specific unit with access to diverse resources" (Gonschor and Beamer 2014:7171). The ahupua'a system separated islands into moku (districts), which were further divided into ahupua'a. This hierarchical land division was devised by ali $i$ (chiefs) on multiple islands to manage water and agriculture and to augment resource production systems for a growing population (Kirch 2010, Beamer 2014). Ho'okupu or tribute from hoa'āina (ahupua'a tenants) sustained the aha ali $i$ (council of chiefs or central government; Beamer 2014, Gonschor and Beamer 2014). Konohiki (land agents or resource managers) were chosen by ali ${ }^{\prime} i$ 'ai ahupua'a (an ahupua'a level chief) to administer and distribute key fisheries and water resources within an ahupua' a for the hoa'àina (ahupua'a residents) (Kirch 1990, McGregor 1996). Ahupua'a fisheries were "certain areas of the sea, from the reefs and, where there happen to be no reefs, from the distance of one geographic mile seaward to the beach at low watermark..." (Kosaki 1954:3). The konohiki and the hoa'äina maintained exclusive rights to ahupua'a fisheries (local-level, small-scale fisheries; Kosaki 1954). Within ahupua'a, families gathered from and cared for particular reefs and respected other family's rights to exclusive harvest (Vaughan 2018).

Increased social stratification also arose around AD 1400, separating social classes via the kapu (forbidden or taboo) system (see Table 3). The kapu system included structured social and religious rituals that organized social interaction and resource use, strictly enforced rules on resource extraction, and defined social interactions between societal classes (Handy and Pūkui 1950, Kirch 2010, Friedlander et al. 2013). Sanctions for being caught breaking kapu could be severe. Evidence from a wide array of sources suggest that these systems were effectively maintained resources and supported large pre-contact population levels estimated to be at least 200,000-400,000 native Hawaiians (Kirch 2007) and perhaps as many as 800,000 or more (Nordyke 1989, Dye and Komori 1992). New and ongoing research is enhancing the understanding of the nuance and variability of Hawaiian resource management systems, including variation between islands and across time (Steele 2015; D. C. K. Forrest and M. B. Vaughan, unpublished data). That research draws on a wealth of emerging primary-source Hawaiian language resources, including 19 th century newspaper accounts, chants, and other historic data used in other recent scholarship (Beamer 2014, Oliveira 2014).

\section{Marine tenure in the Hawaiian Kingdom}

King Kamehameha I united the Hawaiian Islands under one ruler for the first time in AD 1810 and established the Hawaiian Kingdom. Shortly after his death in AD 1819, the kapu system was abolished, and in 1820, arriving protestant missionaries set up schools, which rapidly increased literacy but significantly altered the social fabric of Hawai'i. Along with his advisors, Kamehameha III penned Hawai'i's first written laws in 1839 , which codified ancient relationships with the 'āina (land and sea). The laws delineated property rights of maka āinana (the people, local residents), konohiki (local-level resource appropriators), ali 'i (chiefly) classes, and $m \overline{o ̄}^{-i}$ (high chiefs), all of whom jointly "owned" the land and fisheries. The 1839 laws and Hawai'i's first constitution in 1840 created a new system of government by combining European notions of property with ancient Hawaiian relationships with the land and sea.

Under the 1839 laws, the 1840 constitution, and other subsequent revisions, some fish were reserved specifically for the ali i class. These fish were designated as kapu (restricted) by appointed resource managers, the konohiki. Konohiki were selected for their exceptional resource knowledge and entrusted with resource management decisions at the local level. In exchange for their important caretaking, konohiki were given either one-third of the local fishery catch or exclusive harvest rights for one fish species (Higuchi 2008). As political appointees, konohiki were expected to ensure resource productivity and were removed if poor management decisions led to famine or decreased harvests. Konohiki could also be replaced due to political changes such as the death or removal of a higher-level ali i. Recent research suggests there were many types of konohiki, and in some places, there were multiple konohiki at one time, some who were appointed and others who were selected by the people from among the master fishers in an area (Steele 2015; D. C. K. Forrest and M. B. Vaughan, unpublished data). Further highlighting the administrative complexity, other historical accounts reference the coordination of harvests across multiple ahupua'a within the same moku (Kirch and Sahlins 1994). Closures on a particular species could rotate between two adjoining ahupua'a to ensure continued harvests for residents of both while allowing the species time to replenish in each place (K. Winter, personal communication). 
Table 3. Timeline of major historical events that influenced property rights in Hawai'i coral reef fisheries.

\begin{tabular}{|c|c|}
\hline Date & Event \\
\hline $\begin{array}{l}\text { Pre-contact }(\sim 1450- \\
\left.1500^{\dagger}\right)\end{array}$ & $\begin{array}{l}\text { Practices carried by Polynesian voyagers to Hawai'i evolve into a unique form of management. Evidence from historians and } \\
\text { scholars suggest that these complex management systems were based on ecologically based land divisions embedded within } \\
\text { complex, hierarchical socio-political systems (see Friedlander et al. } 2013 \text { for a more extensive description) }\end{array}$ \\
\hline 1778 & $\begin{array}{l}\text { First Western (European) contact made by Captain James Cook in Waimea Kaua i, bringing disease, Western technology } \\
\text { (including armaments), and opening the Hawaiian islands to Pacific colonial economies }\end{array}$ \\
\hline 1810 & $\begin{array}{l}\text { The Kingdom of Hawai' } i \text { is established when Kamehameha I unifies the Hawaiian Kingdom for the first time, becoming the first } \\
\text { mói i (supreme ruler) for all of Hawai } i \mathrm{i}\end{array}$ \\
\hline 1819 & $\begin{array}{l}\text { Calvinist Missionaries arrive. Kamehameha I dies; his son Liholiho (Kamehameha II) shares the throne with Kamehameha I's } \\
\text { favorite wife Ka'aumanu; the kapu system is abolished }\end{array}$ \\
\hline 1823 & Literacy spreads rapidly across Hawai i \\
\hline 1839 & 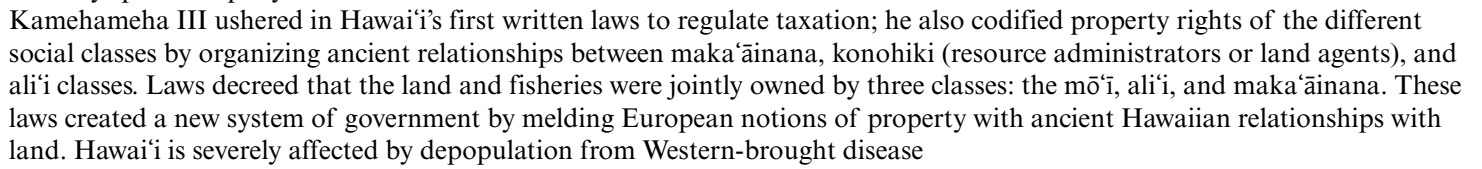 \\
\hline 1840 & $\begin{array}{l}\text { Hawai i's first constitution is written, codifying and refining traditional rights. The constitution affirmed vested land and marine } \\
\text { tenure in the Hawaiian Kingdom }\end{array}$ \\
\hline 1848 & $\begin{array}{l}\text { The Great Māhele divided all lands in the Hawaiian Kingdom, which separated land and divided fee simple titles to land among } \\
\text { the ali } i \text { and konohiki, the government, and the mōi (crown lands). Foreigners could purchase government lands, ushering in a } \\
\text { new era of private property, foreign land ownership, development, and a market-based economy. Land titles were still subject to } \\
\text { the rights of maka'āinana. Claims were required to secure ancestral lands; however, many 'óiwi (native Hawaiians) did not } \\
\text { participate in the registration process, and their fishing rights were dispossessed }\end{array}$ \\
\hline 1850 & $\begin{array}{l}\text { The Kuleana Act allowed maka'āinana to purchase fee simple title to land, further formalized ancient resource rights, } \\
\text { relationships between 'óiwi and the 'âina (land) and access to the benefits of resources. The Act also allowed for a large } \\
\text { government by developing new revenue streams through taxation and protected national interests. The Kuleana Act effectively } \\
\text { institutionalized ahupua'a-level resource rights into law }\end{array}$ \\
\hline 1887 & $\begin{array}{l}\text { Under threat of force, King David Kalākaua signed the Bayonet constitution, making voting rights contingent on property } \\
\text { ownership }\end{array}$ \\
\hline 1893 & The Hawaiian Kingdom is overthrown by a group of American businessmen with the backing of the U.S. military \\
\hline 1900 & $\begin{array}{l}\text { The Organic Act terminates konohiki fisheries unless they were registered within two years; } 300-400 \text { konohiki fisheries are } \\
\text { registered across the Hawaiian Islands; } 248 \text { were not registered, and the government condemned } 37 \text { others. Subsequently, a series } \\
\text { of U.S. court cases uphold the concept of vested fisheries rights, subject to evolving hoa āina (ahupua'a tenant) rights }\end{array}$ \\
\hline 1927 & $\begin{array}{l}\text { The Division of Fish and Game is established for the Hawai'i Territory, ushering in the beginnings of centralized or } \\
\text { bureaucracy-based management }\end{array}$ \\
\hline 1940s-1950s & Documentation of landowners still excluding outsiders from harvesting within their ahupua'a fisheries on $\mathrm{O}^{\prime}$ ahu and Kaua $\mathrm{i}$ \\
\hline 1959 & Hawai'i becomes the 50th U.S. state, seemingly severing locally held fishery rights \\
\hline 1976 & $\begin{array}{l}\text { Hawaiian cultural renaissance; punctuated by the first Hokule'a voyage: a celestially navigated traditional Polynesian voyaging } \\
\text { canoe successfully sails to Tahiti and back; renewed interest in Hawaiian language, culture, music, and mo'olelo (stories and oral } \\
\text { traditions). The Protect Kaho'olawe 'Ohana files suit against the U.S. Navy to prevent bombing on the Island of Kaho'olawe }\end{array}$ \\
\hline 1978 & Hawai'i’s first constitutional convention reaffirms some native Hawaiian rights \\
\hline 1982 & $\begin{array}{l}\text { Division of Fish and Game is reorganized; the Division of Aquatic Resources becomes the state agency charged with managing } \\
\text { fisheries }\end{array}$ \\
\hline 1994 & $\begin{array}{l}\text { Enabling legislation for comanagement (community-based subsistence fishing areas, CBSFAs) is passed by the Hawai'i state } \\
\text { legislature; native Hawaiian community efforts were instrumental }\end{array}$ \\
\hline 1995-1999 & $\begin{array}{l}\text { Pilot CBSFA (comanagement) project occurs at Mo'omomi on the island of Moloka i; the comanaged area is allowed to sunset } \\
\text { without renewal }\end{array}$ \\
\hline 2005 & Miloli $i$ on Hawai' i Island becomes the first permanent, legislatively designated CBSFA in Hawai $i$ \\
\hline 2006 & Hā'ena on Kaua' $\mathrm{i}$ becomes the second permanent, legislatively designated CBSFA in Hawai $i$ \\
\hline$\underline{2015-2016}$ & Hāena rules based on traditional practices are approved; becomes the first active comanaged area since Mo'omomi in 1994 \\
\hline
\end{tabular}

The 1848 Great Māhele divided all lands in the Hawaiian Kingdom, allocating fee simple land titles among the ali'i and konohiki, the government, and the mō'ī, whose lands are often described as crown lands (Van Dyke 2008). The 1850 Kuleana Act was designed to award fee simple land title to maka'āinana, although $<1 \%$ of land in Hawai i was actually awarded to $<29 \%$ of the eligible Hawaiian population (Kame'eleihiwa 1992). The Kuleana Act further institutionalized customary ahupua'a-level rights to natural resources into law by protecting ahupua'a residents' rights to access resources from the mountain to the sea, delineating rights to adequate water to cultivate crops, and providing access to kuleana parcels across the lots of surrounding owners. After the Kuleana Act of 1850, foreigners were allowed to purchase government lands, ushering in a new era of private property, plantations, development, and the introduction of a market-based economy. However, land titles in Hawai i were still subject to maka'ainana rights, one of which was access to the fishery fronting the ahupua'a. 


\section{Overthrow of the Hawaiian Kingdom and annexation}

Under threat of violence, a group of advisors and cabinet members forced King David Kalākaua to sign the Bayonet constitution in 1887, which stripped the monarch of many of his powers and also made voting rights contingent on property ownership (Osorio 2002). Following Kalākaua's death in 1891, Kalākaua's sister, Queen Lydia Liliuokalani, attempted to restore power to the monarchy. In response, a small group of influential foreigners and American plantation owners, backed by the U.S. Navy, illegally overthrew the Hawaiian Kingdom in 1893 (Chock 1995). Following the overthrow and a short period during which the small group of American businessmen who perpetuated it governed Hawai $i$ as an independent republic, the U.S. Congress passed a joint resolution to annex Hawai'i as a U.S. territory (U. S. Congress 1897). Later, the U.S. Congress passed the Organic Act (1900), which formalized provisions of the joint resolution and defined the political structure of the Hawaiian Territory. The Organic Act contained provisions to condemn "private" or community-level rights to nearshore fisheries unless they were vested and registered (Kosaki 1954). The vesting process allowed landowners or konohiki at the ahupua'a level to register to retain their fishery rights. Although past evidence suggested that 101 out of 400 of these ahupua'a fisheries were registered by 35 different owners (Higuchi 2008), recent scholarship suggests that 300-400 konohiki fisheries were registered across the archipelago (Akutagawa 2016). The Hawai i i territorial government, and later, the state government, pursued condemnation of the last onequarter to one-third of registered konohiki fisheries (Murakami and Tanaka 2015). However, in some parts of Hawai' $i$, konohiki fishing rights were legally recognized and informally exercised by community members well into the second half of the 20th century. There is ongoing legal uncertainty regarding whether local-level fishing rights were fully terminated or continue to exist (e.g., figure 1 in Friedlander et al. 2013).

\section{Hawaiian Territory and statehood}

Formal rights to fisheries resources were weakened during the territorial governance period (Kosaki 1954) but persisted into the 1940s and 1950s in some areas (Cramer 2010). Although these rights were seemingly nullified in 1959 as a condition of statehood (Friedlander et al. 2013), many legal questions about the persistence of these rights remain (Akutagawa 2016). Aggressive condemnation efforts by territorial and state governments included payments to konohiki landowners. Government payments were made with the intention of opening all Hawai' $i$ fisheries to the public. These efforts were controversial and highly debated, with proponents of condemnation arguing for openaccess fishing as critical to avoiding food shortages, particularly during World War II, while opponents argued that konohiki fisheries conserved resources that could help replenish other areas. More than 20 court cases considered the legality of condemnation; some were argued all the way to the U.S. Supreme Court, which upheld local-level fishing rights formerly protected by Hawaiian customary and kingdom law. In some areas such as the North Shore of Kaua'i and Kahana Valley on O'ahu, respected de facto local-level rights were maintained for several decades after statehood (Vaughan and Ayers 2016, Montgomery and Vaughan 2018).

\section{Hawaiian renaissance and the emergence of comanagement governance}

Several landmark historical events occurred in Hawai $i$ in the 1970s that were embedded within a larger renaissance of native Hawaiian language, culture, dance, and traditional voyaging and navigation (Lewis 1987). A constitutional convention in 1978 established the Hawaiian language as an additional official language for Hawai' $i$ for the first time since the Hawaiian Kingdom. The convention also recognized that the State of Hawai'i must "...protect all rights, customarily and traditionally exercised for subsistence, cultural and religious purposes and possessed by ahupua'a tenants who are descendants of native Hawaiians who inhabited the Hawaiian Islands prior to 1778 , subject to the rights of the State to regulate such rights" (Hawai' $i$ Constitution Article XII $§ 7,1978$ ).

The 1978 constitutional convention provided the basis for enabling legislation that authorized comanagement nearly 20 years later. Declining marine resources and conflict in the early 1990s precipitated community-level efforts to restore place-based, native Hawaiian resource practices that were once effective in Hawai'i (Poepoe et al. 2007).

Comanagement arrangements through which local communities share formal management authority for coral reef fisheries emerged in the early 1990s. Several Hawai i communities (primarily East Maui and Moloka'i) expressed concern over declining resources and increasing conflicts with outsiders harvesting from rural areas where communities depended on resources for food security (Guth 1999, Higuchi 2008, Ayers and Kittinger 2014). In February 1993, Governor John Waihe'e (to date, the only Native Hawaiian governor in Hawai'i) commissioned a task force to study the role of subsistence activities on the island of Moloka i. Subsistence activities such as fishing, hunting, and gathering were an important source of sustenance for an island whose unemployment rate reached $20 \%$ in the late 1980s. The task force found that subsistence activities provided approximately $28 \%$ of food for the average Moloka $i$ resident and accounted for $>50 \%$ of food for one-quarter of those living there (Matsuoka et al. 1994). Documentation of the importance of local resources for food security in rural communities such as Moloka'i, along with lobbying by several community groups and environmental nongovernmental organizations, secured passage of legislation in 1994 to protect community fisheries.

This legislation authorized the DAR to partner with Hawai i communities to create community-based subsistence fishing areas (CBSFAs) "for the purpose of reaffirming and protecting fishing practices customarily and traditionally exercised for purposes of native Hawaiian subsistence, culture, and religion" (Hawai 'i State Legislature Act 271 of 1994; Higuchi 2008). The legislation also initiated a pilot community managed CBSFA at Mo'omomi and Kawa'aloa bays on Moloka' $i$ and allowed communities across the Hawai' $i$ to partner with the state to create rules for their adjacent marine areas based on the 1978 Constitution (Hawai i State Legislature Act 271 of 1994; see Higuchi 1994 for a detailed explanation of the CBSFA legal process). Although other community-based fisheries management structures exist (Maurin and Peck 2008, Tissot et al. 2009, Rossiter and Levine 2014), 
CBSFAs are the primary mechanism through which communities have pursued comanagement in Hawai'i. While local efforts secured passage of enabling legislation for comanagement in Hawai $i$, communities in other parts of the Pacific were also working for renewal of customary management (Johannes 2002), and the idea of comanagement was also germinating globally (Jentoft 1989, Pinkerton 1989, Baland and Platteau 1996).

\section{Contemporary comanagement efforts in Hawai i}

Comanagement through CBSFAs in Hawai' $i$ has gathered momentum in the past decade for multiple reasons. First, the DAR and the Department of Land and Natural Resources (DLNR) are underfunded, understaffed, and fisheries have declined under Hawai i fishing regulations (Friedlander and DeMartini 2002, Williams et al. 2008, Page et al. 2013, Vaughan and Ayers 2016, Montgomery and Vaughan 2018). Second, these regulations are poorly tailored to local social and ecological conditions (Schemmel and Friedlander 2017), and are often underenforced, leading to de facto open access in many areas (Friedlander et al. 2013, Ayers et al. 2017). Third, many communities are concerned about declining resource health and are motivated by a desire to restore local care in decision making. These motivations are captured in statements such as, "We want to be sure there are fish for our grandchildren," "We need to perpetuate fishing lifestyles of our community," and "We are responsible for taking care of our own reef" (Vaughan 2018). Many Hawai i communities envision comanagement efforts as a step toward restoration of local-level governance, which is also tied into issues of social justice, food security, and local-level sovereignty. However, formal pathways for state government to devolve management authority to communities have been difficult to establish despite mobilization, lobbying, and political pressure by at least 30 increasingly networked community groups across the main Hawaiian Islands (Vaughan 2018). Opposition to establishment of CBSFAs has occurred from within the state bureaucracy in charge of managing resources, commercial fishing interests, dissenting factions within communities, and ocean tourism businesses such as snorkeling and tour operators that use the areas for commerce (Ayers and Kittinger 2014, Ayers et al. 2017). The long, complex state rulemaking process provides many opportunities to thwart community-led efforts with meetings primarily held on $\mathrm{O}^{\prime}$ ahu, which is an expensive trip (approximately USD \$200 round trip for airfare alone) for rural, outer island community members.

Until recently, it has been difficult for communities to gain traction toward comanagement implementation. The Mo'omomi and Kawa'aloa CBSFA Pilot Project was allowed to sunset in 1999 after four years because of community-state disagreement over boundaries, sharing management responsibilities, and a lack of cooperation (Guth 1999, Ayers and Kittinger 2014). Despite legislation designating Miloli i on Hawai'i Island in 2005 and Hāena on Kaua 'i in 2006, DAR did not approve administrative rules to designate a single CBSFA until the Hā'ena rules were approved in 2015 (Kittinger et al. 2012, Vaughan and Caldwell 2015, Vaughan et al. 2016). In 2006, Hā'ena was able to capitalize on political support generated on the occasion of the retirement of its powerful local state legislator to achieve a legislative CBSFA designation (Vaughan and Caldwell 2015, Vaughan 2018). Community members and supporters then worked for nearly a decade to develop and revise local-level rules based on customary norms and practices until the Board of Land and Natural Resources and Governor approved them in August 2015 (Vaughan et al. 2016). Locally devised and state-vetted rules included gear-based restrictions, revised bag limits for certain species, and a small no-take marine protected area (Division of Aquatic Resources 2016). This effort required documentation of customary practices through archival research and elder interviews; four different marine ecological studies; three public hearings; 60 community meetings; 100 s of hours of volunteering by community leaders; support from nongovernmental organizations, academics, and personnel from three different state agencies (Vaughan and Caldwell 2015); and testimony from other network communities working on similar efforts. In 2007, the year after Hā'ena achieved its legislative designation, three other Hawai' $i$ communities and three entire Hawaiian islands submitted similar bills for formal comanagement under the CBSFA statute (Ayers and Kittinger 2014, Vaughan 2018). The Hawai $i$ legislature did not pass any of them. Only one of these communities, Mo'omomi, Moloka i, is close to securing another CBSFA designation (Vaughan 2018). Another community on Hawai'i Island, Ka'ūpūlehu, passed one rule into law, a 10-year ban on all fishing to give the fishery an opportunity to rest and replenish. The effort to pass this rule took $>20$ years (GilibertiIppel 2016).

A key challenge for communities has been a misconception that they are exclusive and aimed at preventing outsiders from fishing in their areas (Richmond and Levine 2012, Vaughan 2018). While historically, fishing rights were limited to local area residents, most of Hawai'i's coastline is public (other than military bases), and there is no right to exclude anyone (Higuchi 2008). One of the strengths of a movement for comanagement in Hawai'i is the common message to fish responsibly in a way that sustains resources, respects customary practices, and highlights the need to care for one's fishing areas, rather than guaranteed rights to fish or exclude others (Akutagawa et al. 2016). The Hawaiian adage Lawai a pono (to fish in a balanced and correct way) has gone viral on social media and has become a key message of the Hawai' i comanagement movement, a movement that has begun to shift the dialogue from "rights to fish" to a responsibility to manage, care for, and restore Hawai i coral reef fisheries (Vaughan 2018). See Fig. 1 for a graphical depiction of coral reef management changes over time in Hawai i from Polynesian arrival to present day.

\section{RESULTS}

Here, we present the findings of an institutional analysis of two time periods and three governance regimes: historical marine tenure present during the Hawaiian Kingdom (described below as historical marine tenure), with contemporary centralized or bureaucracy-based management, and contemporary comanagement in Hawai'i. First, the hierarchy and decision-making authority (Table 4) is compared, followed by an analysis of the property rights components under the two governance arrangements (Table 5).

\section{Hierarchy and authority for rules}

Hierarchical administrative decision making in the IAD framework is divided into four levels: meta-constitutional, constitutional, collective choice, and operational. Metaconstitutional represents the highest level of institutions that 
Table 4. Nested rules hierarchy and authority for small-scale fisheries in the Hawaiian Kingdom (1810-1892), contemporary centralized management (1982-2018), and contemporary comanagement (1994-2018).

\begin{tabular}{|c|c|c|c|}
\hline \multirow{2}{*}{$\begin{array}{l}\text { Level of analysis and arena of } \\
\text { choice }\end{array}$} & \multicolumn{3}{|c|}{ Governance arrangement } \\
\hline & Historical marine tenure & Centralized management & Comanagement \\
\hline $\begin{array}{l}\text { Meta-constitutional: individual } \\
\text { actions that directly affect rules that } \\
\text { affect Constitutional situations }\end{array}$ & $\begin{array}{l}M \bar{o} i t \text { ruling monarch (absolute } \\
\text { monarchy } 1810-1840 ; \text { constitutional } \\
\text { monarchy } 1840-1892 \text { ) }\end{array}$ & $\begin{array}{l}\text { Federal government/U.S. } \\
\text { Constitution/Federal statutes }\end{array}$ & \\
\hline $\begin{array}{l}\text { Constitutional: individual actions } \\
\text { that directly affect rules that affect } \\
\text { collective choice situations }\end{array}$ & $\begin{array}{l}\text { Alit } i \text { (ruling chief on each island), } \\
\text { aha alit } i \text { (council of chiefs) }\end{array}$ & $\begin{array}{l}\text { State of Hawai'i/Hawai'i State } \\
\text { Constitution }\end{array}$ & \\
\hline $\begin{array}{l}\text { Collective choice: mutually agreed } \\
\text { upon actions that affect rules that } \\
\text { affect operational situations }\end{array}$ & $\begin{array}{l}\text { Aliti 'ai moku (ruling chiefs in each } \\
\text { district), made decisions in } \\
\text { consultation with the ali' } i \text { 'ai } \\
\text { ahupua'a (ruling chief of lesser rank } \\
\text { at the ahupua'a level) and the } \\
\text { konohiki (agent or land manager) }\end{array}$ & $\begin{array}{l}\text { Board of Land and Natural } \\
\text { Resources; State of Hawai'i } \\
\text { Resource Management Agency } \\
\text { (DLNR) }\end{array}$ & \\
\hline $\begin{array}{l}\text { Operational: rules-in-use that affect } \\
\text { everyday user decisions }\end{array}$ & $\begin{array}{l}\text { Ali'i'ai ahupua'a appointed a } \\
\text { konohiki the authority to } \\
\text { appropriate resources and devise } \\
\text { rules in concert with expert fishers } \\
\text { and hoa'àina (ahupua'a tenants) }\end{array}$ & $\begin{array}{l}\text { Division of Aquatic Resources } \\
\text { (DAR)/Division of Conservation } \\
\text { and Resource Enforcement } \\
\text { (DOCARE) }\end{array}$ & $\begin{array}{l}\text { Rulemaking authority shared } \\
\text { between users and resource } \\
\text { management agencies (DAR/ } \\
\text { DOCARE) }\end{array}$ \\
\hline
\end{tabular}

guide and constrain how decisions are made at the constitutional level. The constitutional level prescribes how decisions may be made at the collective choice level. Collective choice is most often thought of as collective decision making to decide on operationallevel rules such as fishing regulations. Most research describes collective choice occurring within community-based management at the local level. Our research reveals that collective choice decision making over operational rules, particularly in comanagement, may not occur at the local level.

Although it may appear that the historical marine tenure system, contemporary centralized management, and comanagement are arranged in a classic bureaucracy, the historical marine tenure system exhibits polycentric institutional structure characterized by multiple overlapping centers of authority (Ayers et al. 2017). Historical accounts suggest that decision making was sometimes coordinated at the regional (moku) level, whereas other times, it was devolved to the local level (ahupua'a level). Although administrative decisions were sometimes coordinated at higher political levels, operational decisions were made locally without direct supervision from higher administrative units. Local-level autonomy was made effective by the wealth of local-level resource knowledge. Master fishers worked with enabled local managers (konohiki) to create adaptive rules that maximized resource productivity. Depending on the scope of rules (for both centralized management and comanagement under contemporary governance arrangements), they must still be approved at multiple levels of state government, and thus, both fisheries rulemaking structures are embedded within a classic bureaucratic administrative structure.

\section{Meta-constitutional}

The meta-constitutional level holds the authority to develop constitutional-level rules or the highest level rules that structure rules interactions at all lower levels. The highest level of authority was found to be present in all three management regimes. Under historical marine tenure, the mōi ī (absolute monarch) presided over the meta-constitutional level (Beamer 2014). Today, however, the U.S. government and the U.S. Constitution represent the umbrella framework and institutional structure under which all other levels of government operate in contemporary centralized management and comanagement. In addition to the U.S. Constitution, the Public Trust Doctrine also ensures that with few exceptions, most U.S. rivers, oceans, and coastlines remain open to the public and are de facto common property of all U.S. citizens (Sax 1969). The 14th amendment of the U.S. Constitution, the equal protection clause, also guarantees that U.S. laws apply equally to everyone. This can be problematic for the design of rights-based management and operational-level rules that seek to privilege local users or exclude outside groups. Rulemaking at lower levels must take these constraints into account when attempting to limit access.

\section{Constitutional}

The ali $i$ nui (island high chief) held the authority to preside over the constitutional level for the Hawaiian Kingdom. In the role of high chief, the ali'i nui attended political and administrative meetings with the aha ali $i$ (council of chiefs) and took directives from the mōî. Today, the executive branch of the Hawai'i state government, headed by a democratically elected governor, represents the constitutional level for contemporary centralized management and comanagement. The Hawai'i state constitution authorizes the executive branch of the state government to manage resources as well as to protect and regulate traditional practices and resources that are important for native Hawaiian subsistence, culture, or religion.

\section{Collective choice}

In the historical system, the ali $i$ ' ai moku (district-level chief) retained authority over the collective choice in the historical marine tenure system, sometimes coordinating lower ahupua'alevel decision making. In the current comanagement system, the governor-appointed, seven-member Board of Land and Natural Resources, or Land Board, represents the collective choice level 
Fig. 1. Graphical depiction of historical changes and key events affecting Hawai i coral reef fisheries management.

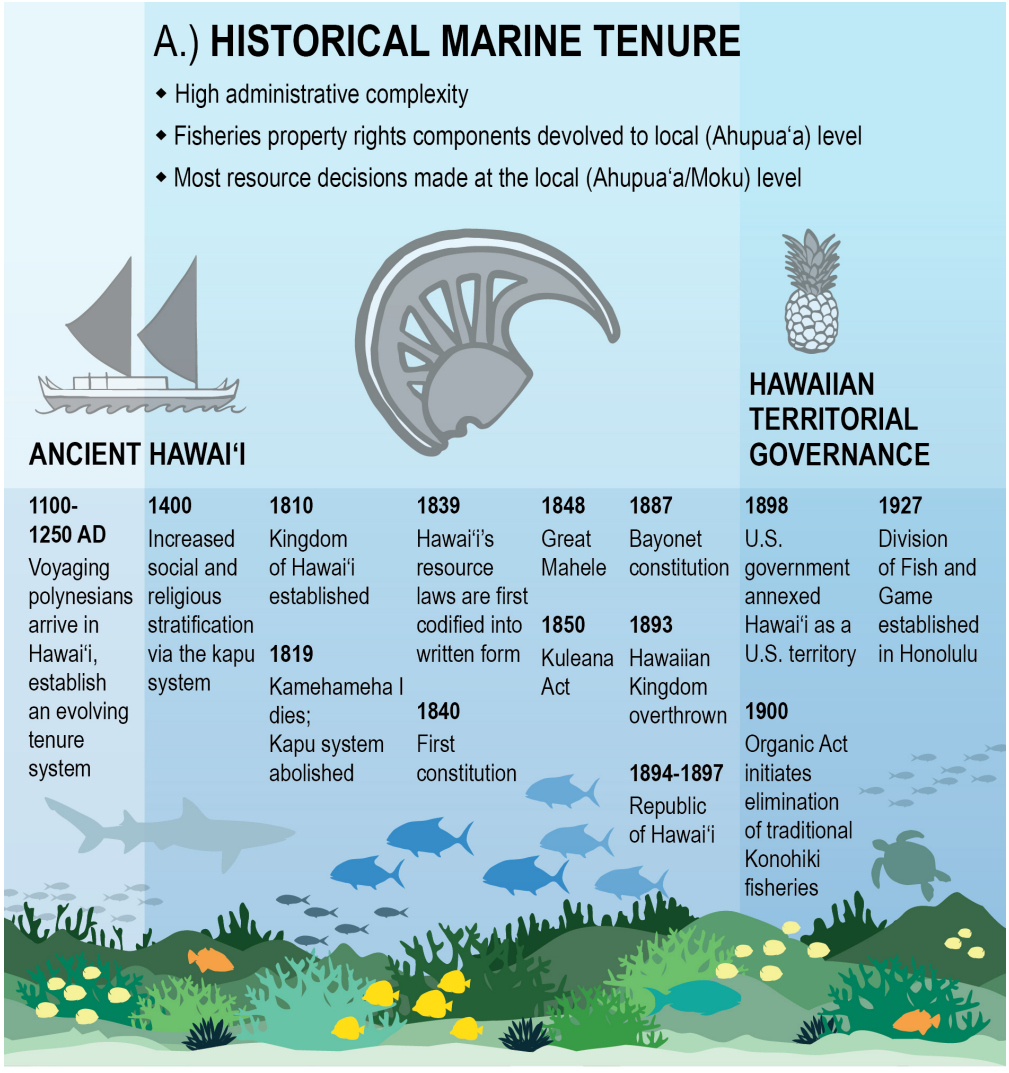

\section{B.) CENTRALIZED MANAGEMENT}

- High administrative complexity

- Fisheries property rights components centralized in a state bureaucracy

- Resource decisions subject to layers of review and approval

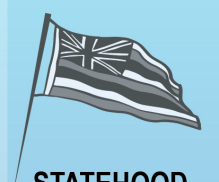

STATEHOOD

$1959 \quad 1970$ s

Statehood Hawaiian

$$
\text { cultural }
$$
renaissance

1978

Constitutional

convention

reaffirms

some Native

Hawaiian rights
C.) CO-MANAGEMENT

- High administrative complexity

- Fisheries property rights components centralized in a state bureaucracy (except shared management rights)

- Local resource decisions permitted, subject to layers of review and approval
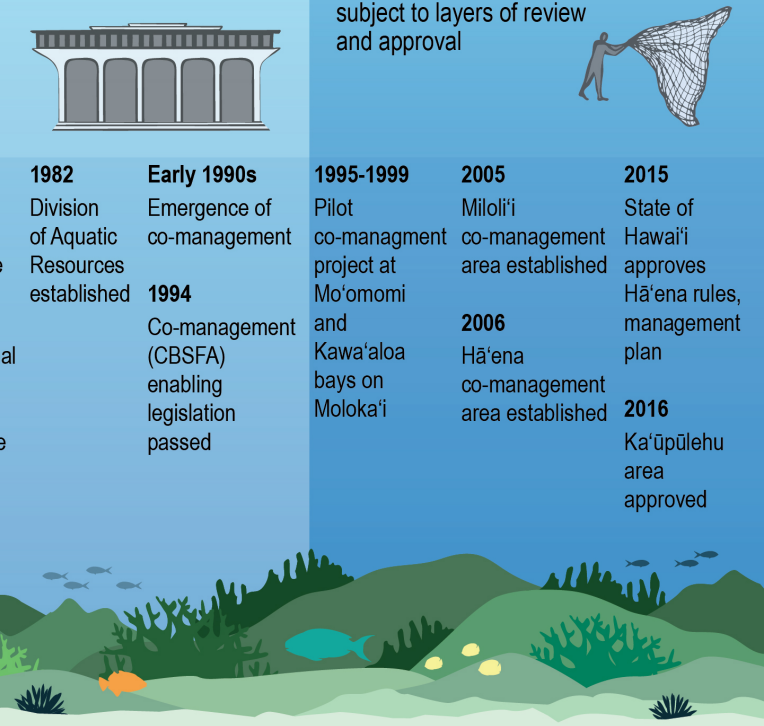
Table 5. A comparison of historical customary marine tenure and comanagement institutional arrangements in Hawai' $\mathrm{i}$ (property rights). Framework adapted from Schlager and Ostrom (1992).

\begin{tabular}{|c|c|c|c|}
\hline Property rights component & Historical marine tenure & Centralized management & Comanagement \\
\hline $\begin{array}{l}\text { Access: right to enter a resource } \\
\text { area }\end{array}$ & Hoi'āina and konohiki only & $\begin{array}{l}\text { Anyone, subject to regulations that } \\
\text { apply equally }\end{array}$ & $\mathrm{n} / \mathrm{a}$ \\
\hline $\begin{array}{l}\text { Withdrawal: right to withdraw or } \\
\text { harvest resource units }\end{array}$ & $\begin{array}{l}\text { Hoi àina subject to konohiki rules } \\
\text { and ho'okupu provided to ali'a ai } \\
\text { ahupui'a }\end{array}$ & $\begin{array}{l}\text { Anyone, subject to resource rules } \\
\text { and regulations }\end{array}$ & $\begin{array}{l}\text { Anyone, subject to rules based on } \\
\text { customary practices }\end{array}$ \\
\hline $\begin{array}{l}\text { Exclusion: right to exclude others } \\
\text { from entering a resource area or } \\
\text { harvesting resource units }\end{array}$ & $\begin{array}{l}\text { Konohiki enforced palena } \\
\text { (boundaries) at the ahupui'a level; } \\
\text { hoi'āina from other ahupui'a needed } \\
\text { permission to enter and harvest }\end{array}$ & $\begin{array}{l}\text { No one can be excluded unless rules } \\
\text { specify that everyone is excluded }\end{array}$ & $\mathrm{n} / \mathrm{a}$ \\
\hline $\begin{array}{l}\text { Management: right to make } \\
\text { operational rules and enforce } \\
\text { sanctions }\end{array}$ & $\begin{array}{l}\text { Konohiki, in consultation with kilo } \\
i^{\prime} a \text { (master fishermen or fish } \\
\text { spotters) and hoi'äina, subject to } \\
\text { appointment by ali'i 'ai ahupui'a } \\
\text { (ahupui'a level chief) }\end{array}$ & $\begin{array}{l}\text { Division of Aquatic Resources } \\
\text { (DAR) develops rules, subject to } \\
\text { attorney general approval, public } \\
\text { input, majority approval by the } \\
\text { Board of Land and Natural } \\
\text { Resources (BLNR), and approval by } \\
\text { the Governor of Hawaici }\end{array}$ & $\begin{array}{l}\text { Rules devised at the community } \\
\text { level in consultation with DAR, } \\
\text { subject to approval by the attorney } \\
\text { general, public input, majority } \\
\text { approval by BLNR, and the } \\
\text { Governor }\end{array}$ \\
\hline $\begin{array}{l}\text { Alienation: right to sell or lease any } \\
\text { of the above rights }\end{array}$ & $\begin{array}{l}\text { Some alienation occurred in the late } \\
1800 \text { s during the transition to a } \\
\text { market economy as some konohikis } \\
\text { leased or sold their rights to certain } \\
\text { species to commercial fisheries for } \\
\text { economic gain while still practicing } \\
\text { subsistence fishing }\end{array}$ & $\begin{array}{l}\text { Only the State of Hawai'i can sell or } \\
\text { lease any of the above rights, except } \\
\text { ceded lands, which are subject to } \\
\text { collective rights of native } \\
\text { Hawaiians; their sale or lease } \\
\text { requires approval by both houses of } \\
\text { the Hawai'i state legislature }\end{array}$ & $\mathrm{n} / \mathrm{a}$ \\
\hline
\end{tabular}

in contemporary centralized management and comanagement. The Land Board must approve any changes in operational-level rules, subject to final approval by the governor.

\section{Operational}

The ali'i 'ai ahupua'a appointed local-level konokihi (resource appropriators) worked together with master fishers and residents living in the area to devise operational-level rules. In contemporary centralized management, rulemaking authority is ceded to the DAR, with final approval by the appointed Land Board and the Hawai' $i$ Governor. Under comanagement, formal operational-level rulemaking authority is shared between community members and the DAR and is enforced by the Division of Conservation and Resource Enforcement (DOCARE), which is the state-level marine resource management and enforcement agency.

\section{Property rights components}

Schlager and Ostrom (1992) define five property rights components that are integral to the analysis of natural resource governance arrangements: access, withdrawal, exclusion, management, and alienation. Possession of these rights under historical marine tenure, contemporary centralized management, and comanagement is presented in Table 5. A description of these rights in each governance arrangement is provided next.

\section{Access and withdrawal}

Under historical marine tenure, both local (ahupua'a) tenants and local resource managers possessed the right to enter resource areas and harvest resource units. Under centralized management, the Public Trust Doctrine and the Hawai' i state constitution ensures that coastal and marine access may not be restricted, subject to certain rules and regulations. In most areas, anyone may enter coastal and marine areas to fish, except for areas where fishing activity is prohibited by all users. Likewise, in contemporary comanagement, rights to exclude are not currently recognized, so there is no de jure managed access to resources. As a result, anyone may enter a resource area and harvest resource units subject to existing resource rules and regulations. Access and withdrawal rights are subject to operational-level rules under both governance arrangements in both time periods.

\section{Exclusion}

Under historical marine tenure, local resource managers enforced palena (boundaries) at the ahupua'a level; ahupua'a tenants from other ahupua'a required permission from the konohiki to enter and harvest. Hoa'äina retained rights within ili (subareas of an ahupua'a). In both contemporary centralized management and comanagement, no one can be legally excluded from resource areas except under state coercion.

\section{Management}

Management rights entail the rights and responsibilities associated with making decisions regarding access, withdrawal, exclusion, and alienation. Konohiki retained management rights in historical marine tenure, but their rulemaking rights required consultation with master fishers and ahupua'a tenants. Moreover, their management rights were subject to changes in the Hawaiian Kingdom political landscape and political change at higher levels of authority. DAR holds management rights in contemporary centralized management, subject to approval by the Land Board. Community members share some management rights to codevelop operational-level rules (fishing regulations) with the DAR in contemporary comanagement.

\section{Alienation}

Some alienation occurred under historical marine tenure during the mid- to late 1800 s as the Hawaiian Kingdom transitioned to 
a market economy. For example, some konohiki leased or sold their rights to certain species to commercial fisheries for economic gain while still practicing subsistence fishing (Kirch 2010, Kittinger 2010). Today, the State of Hawai'i may sell or lease any of the property rights components subject to the state and federal constitutions. However, ceded lands, sometimes referred to as crown lands, can limit state-level alienation rights. Ceded lands were the lands once owned by the Hawaiian mōi that today are treated as a collective property right shared by all native Hawaiians (Van Dyke 2008). Currently, the sale, transfer, or lease of crown lands is subject to a two-thirds vote by both the State of Hawai'i House of Representatives and the Senate (Van Dyke 2010).

\section{DISCUSSION}

Governance of natural resources has changed substantially over the last 200 years in Hawai'i, with major changes in decision making, property rights, and institutional arrangements. Accompanying these changes, resources have declined considerably (Kittinger et al. 2011, McClenachan and Kittinger 2012). In response, community actions have led to the emergence of a new governance arrangement, comanagement, that includes some aspects of local-level management and incorporates aspects of the historical marine tenure system (Ayers and Kittinger 2014). Our analysis of property rights raises several issues relevant to the performance of rights-based fisheries management approaches such as comanagement. These issues include devolution of property rights to the local level, matching administrative with social-ecological complexity, the importance of historical context and narratives in shaping solutions, and the perceived legitimacy of governance arrangements. We next address each of these issues, drawing from our research and suggesting pathways to strengthen comanagement systems to improve social and ecological performance.

\section{Devolution of property rights to the local level}

Global assessments of fisheries management have shown that devolving rights to users can confer stewardship incentives, producing better outcomes (Costello et al. 2008). However, there can be unintended consequences associated with rights based approaches, including elite capture of benefits (Cinner et al. 2012, MacNeil and Cinner 2013) and consolidation of rights, causing loss of employment, fleet diversity, and a way of life for fishers and associated industries (Kasperski and Holland 2013, Rust 2013). It is important to be aware of these and other unintended consequences during the institutional design process for rightsbased management. If not, institutions and incentives may be misaligned. Costello et al. (2008) explain that rights-based fisheries may encompass many approaches or tools, but the main point is that fishers, cooperatives, or, as we describe in this case, communities, receive a secure asset that incentivizes them to take better care of it. Costello et al. (2008) may have viewed "a secure asset" in economic terms, but in this case, comanagement could be viewed as a quasi-secure asset characterized by partial excludability and rivalry.

For example, in the Hā'ena CBSFA, management rights allowed the community to devise rules that indirectly privilege residents with significant knowledge of the area and experience using customary fishing practices (Division of Aquatic Resources 2016). For example, rules require harvesting he'e (octopus) by hand or with a stick less than two feet long, a customary harvesting method of live capture. This method puts the fisherman or fisherwoman at risk of getting bit by the octopus' sharp beak and requires more skill than spearing. He'e is the Hawaiian word used to describe two species of cephalopods common to Hawai i coral reef areas (Octopus cyanea or Octopus ornatus). Even though no one is directly excluded through the he'e gear restriction, the rules do serve as a barrier to entry for less skilled fishers not practiced in customary harvest. While keeping the fishery open to all, the rules still restrict access to resources important to the Hā'ena community for social, cultural, and food security purposes. The rules also create a slightly more secure asset that may increase community-level stewardship and foster sustainable harvests. Here, constraints at the meta-constitutional level force Hawai $i$ communities to be creative in their rulemaking to regulate access indirectly (Vaughan and Caldwell 2015, Vaughan et al. 2016). Despite the novelty of their approach, it may fail to confer full stewardship incentives to communities over the long term (as described in much of the economic literature on rights-based fisheries) and may eventually hinder their success (Grafton et al. 2006).

In comanagement, rights are often not fully devolved to communities or user groups (Pinkerton 1999, Pomeroy et al. 2001). While most analyses of rights-based fisheries are commercially oriented rather than subsistence based, data on contemporary comanagement presented in this case also indicates less than full devolution of rights to local resource users. Under contemporary comanagement in Hawai 'i, communities "sharing" management authority are allowed to create rules for their area, but other rights such as access and withdrawal, exclusion, and alienation are not fully conferred to the local level. Hā'ena's CBSFA legislation mandated that community and government agencies work together to create and enforce rules. However, after 10 years of rulemaking, as the rules awaited endorsement by the governor to become law, DLNR required that the Hā'ena community develop a management plan. Language in the plan stipulated that communities have no authority to enforce rules, and that enforcement authority resides solely with DLNR's enforcement branch, DOCARE. Hawai'i communities pursuing comanagement have not received the full suite of rights and can only exert rights to manage through advancing site-based rules for adoption by the state, a process subject to multiple bureaucratic approvals and public hearings (Ayers and Kittinger 2014). This process can take decades to complete and precludes adaptive management (Vaughan and Caldwell 2015).

As a result of the current governance system, comanagement in Hawai' $i$ has thus far been implemented on a piecemeal basis. Outside of Hawai' $i$, other countries have ushered in large-scale implementation of rights-based approaches swiftly and definitively. Marine management in Chile transformed dramatically after the Chilean Fishing and Aquaculture Law, which mandated comanagement in 1991 (Gelcich et al. 2006). This 1991 law ushered in statewide change in property rights by devolving exclusive benthic harvesting rights to local fishers. The near collapse of a Chilean Abalone (Concholepas concholepas) and the success of a small experiment to devolve exclusive benthic harvest rights drove passage of the law. Although some difficulties were associated with the abrupt transition from the traditional management system (Gelcich et al. 2006), there is evidence of 
positive social and ecological outcomes as a result of comanagement governance in Chile, and the law is generally considered a success (Gelcich et al. 2008, 2010). If comanagement in Hawai i is ever going to be implemented beyond a few small and isolated areas or demonstration projects, more rights must be devolved to communities. To devolve more rights, perhaps a different set of constitutional-level rules akin to Chile's 1991 law that changes local fisheries property rights arrangements may be necessary to facilitate wider implementation. New constitutionallevel rules could shift the landscape to be more favorable to the establishment of comanagement by reducing administrative barriers and returning a fuller set of rights to the communities that traditionally held these rights.

\section{Matching administrative with social-ecological complexity}

Rights-based approaches to management may take many forms and offer a diversity of policy instruments available to resource appropriators. However, rights-based approaches, including comanagement, may not be successful without administrative structures commensurate with the complexity of the socialecological systems they govern (Ostrom 1998). State-level spending on natural resources in Hawai' $i$ is among the lowest in the nation, averaging 1-4\% of overall state budgets from 19972013 (Teneva 2016). A consequence of this lack of natural resource spending is a lack of institutionalized enforcement and a de facto open access property rights arrangement for most smallscale fisheries in Hawai i (Jokiel et al. 2011, Finkbeiner et al. 2015). Open access areas across the main Hawaiian islands show declines in biomass and apex predators (Friedlander and DeMartini 2002). One explanation for low spending and a lack of enforcement is that there is no license program for noncommercial fishing activity (Study Group 2016). A fishing license program typically raises revenue for enforcement, education, and data collection for management.

Conflict is another consequence of low spending on natural resources and enforcement. Up to $90 \%$ of coral reef fish caught in Hawai $i$ are consumed or shared by fishers (Friedlander and Parrish 1998, Kittinger et al. 2015, Grafeld et al. 2017), demonstrating widespread dependence on the ocean for sustenance. The Governor's task force study, which helped precipitate comanagement, found that nearly two-thirds of residents of Moloka'i Island fished regularly, and more than onethird engaged in ocean gathering activities, gathering limu (seaweed) and opihi (an intertidal limpet), both of which are culturally important local foods, and fishing and hunting activities provided more than one-third of food for island residents (Matsuoka et al. 1994). Given the dependence on resources on Moloka $i$ and their corresponding decline, it is not surprising that conflict, and even violence, has erupted between Moloka $i$ residents and visiting fishermen from neighboring islands over increasingly scarce resources (Davis 2014). Likewise, it is not surprising that Moloka' $i$ residents would seek to strengthen local property rights to avert the tragedy of the commons.

To manage these conflicts, a robust administrative structure, including a strong community presence, should match the complexity of the social-ecological system. This could entail sharing authority with communities and increasing management funding to augment planning staff, data collection, monitoring, and enforcement efforts, which are all vital governance components. State resource health monitoring programs focus on annual assessments such belt transects. In contrast, community efforts to monitor changes in resource health occur year-round, incorporating multiple methods that track ecosystem change from mountain to sea to document seasonal variations such as spawning times of different species and how they vary with lunar cycles and weather patterns (Montgomery and Vaughan 2018). On the social side, governance arrangements must include the many layers of community connected to a fishery, including fishers and those with whom they share fish, and not just people living in an area, but those that may have been forced to move away (Vaughan and Vitousek 2013).

However, community-level enforcement remains a challenge because efforts to deputize community members have met administrative and legal resistance at the state constitutional level. Legally, community members are not allowed to enforce resource rules, which is considered a key element of community-based governance (Ostrom 1990). At this time, community members must report incidents to the state-level DOCARE, the enforcement arm of the DLNR. As a division, DOCARE is understaffed relative to the scale of its patrol areas. For example, on the island of Kaua'i, there are just nine DOCARE officers to patrol from mauka to makai (from the mountains out to three miles in the ocean), approximately $1430 \mathrm{~km}^{2}$. Administrative structures must include adaptive and interwoven approaches to monitoring, education, communication, compliance, and enforcement that are worthy of interdependent, complex, socialecological systems. These structures must be able to recognize, measure, and assess mountain to sea impacts on coastal ecosystems, and their increasing variability due to climate change.

\section{Importance of historical context in shaping current solutions}

Although fisheries management in Hawai $i$ has changed substantially over the 19th and 20th centuries, customary practices and understanding of historic marine tenure systems endure within Hawai i local knowledge systems (Maly and Maly 2003, McGregor 2007) and is being revitalized through restoration of community-level natural resource management practices. Management failures and declining resources are often attributed to the arrival of Western conceptions of management (bureaucratic administration and centralization) and a departure from native Hawaiian practices, values, and ways of knowing (Ayers and Kittinger 2014). When generating solutions to contemporary resource management dilemmas in Hawai i $\mathrm{i}$, many of these historical narratives, or "artifacts" (Ostrom 1980), continually resurface and are reinterpreted and adapted to today's context.

Still, institutional analysis of historical marine tenure, contemporary centralized management, and comanagement reveal vast differences in efficiency, accountability, and resource outcomes. Some Hawai i communities frame the emergence of comanagement as a small component within a larger political movement toward restoring native Hawaiian sovereignty or a renewal of native Hawaiian values and relationships with the natural world (Vaughan and Caldwell 2015, Vaughan et al. 2016). More than two dozen communities are currently in various stages of comanagement planning across Hawai'i (Higuchi 2008, Ayers and Kittinger 2014, Levine and Richmond 2014), indicating 
dissatisfaction with the current management regime, the larger political system, and a desire to reintegrate aspects of historical marine tenure into contemporary management.

Some dissatisfaction with contemporary centralized management may be addressed by paying closer attention to historical and cultural context in designing fisheries management regimes. Development scholars have documented institutional failures in a multitude of global cases, stemming from solutions imposed by external forces that do not fit local knowledge, customs, and context (Scott 1988, Boettke et al. 2008). Although evidence reveals declines in resource productivity from ancient Hawai' $i$ to present day (Kittinger et al. 2011), there is a prevailing notion among many Hawaiian communities that aspects of customary marine tenure can be still be effective. Examples include placebased rules based on customary practices and values, or using the Hawaiian lunar calendar to limit harvest during spawning periods (Poepoe et al. 2007, Schemmel and Friedlander 2017). Local monitoring and educational programs can help build awareness and change perceptions over time (Vaughan et al. 2016) and are needed to sustain decades-long comanagement transitions faced by Hawai'i communities. Comanagement transitions have also taken significant time and resources, e.g., 10 years or longer, in other areas of the world (Yandle 2003, Gelcich et al. 2010), which may also indicate the difficulty of changing behavioral patterns, the "stickiness" of institutions, or the reluctance of governments to cede authority.

\section{Perceived legitimacy of governance arrangements}

Jentoft (2000:145) posited a positive relationship between legitimacy and authority: "Autonomy (or the lack of such) is an essence of power as such it needs legitimation. The lesser the autonomy, the greater the legitimation problem." Although Hawai'i's historical marine tenure system was last implemented under a constitutional monarchy, in many ways, it was more legitimate than contemporary comanagement in fisheries because management authority was devolved to lower levels where local expertise could be integrated into management. In the Hawaiian Kingdom, chiefs and resource managers were not selected for leadership positions through democratic vote, yet success and tenure of ali' $i$ and konohiki depended on their ability to manage resources effectively while distributing harvests equitably throughout an ahupua'a. To ensure accountability, the Hawaiian Kingdom decentralized decision making to local resource managers, who consulted with and placed great value on information gathered from expert fishermen (Vaughan and Ayers 2016). Even though ali $i$ and konohiki held a great amount of authority, their position of power was tenuous. People who did not respect an area chief were free to move elsewhere, and unjust ali' $i$ could be removed, or even killed, if their decisions were deemed unfair or led to resource decline (Kirch 2007, Van Dyke 2008, Beamer 2014).

In contrast, very little management authority is devolved to contemporary Hawai'i communities through comanagement. Communities are dependent on unionized government civil servants that may only be fired for cause, and on resource regulations that are largely unenforced because of low agency budgets. Further, the administrative rulemaking process in Hawai $i$ is designed to provide four or five opportunities for public input (Kittinger et al. 2012) but, in many ways, reinforces or amplifies existing power relations. For instance, public meetings are almost always held at agency offices located in the urban core of Honolulu. Because of the high cost of living in Hawai' $i$, many community members advocating for comanagement often work several jobs to make ends meet or are retired and live on a fixed income. These factors make travel and time off to attend meetings and provide in-person testimony prohibitively expensive and difficult. Conversely, entrenched commercial or other organized interests opposed to comanagement may employ trained communications staff and legal counsel to lead strategy, threaten litigation, or contest community claims. In other public fisheries arenas, more nuanced rhetoric and argumentation in public processes by paid professionals has effectively influenced policy (Wilson and McCay 1998).

If fishers do not consider management by fishers legitimate, they may break rules or seek ways to change them (Jentoft 2000, Acheson 2003). However, if participants feel that their voices are heard, then they can often live with unfavorable outcomes (Jentoft 2000). There is much evidence that existing participatory and decision-making structures are ineffective in Hawai'i. Recent research suggests that the participatory rulemaking process is one of the biggest barriers to comanagement in Hawai $i$ (Levine and Richmond 2014, Vaughan and Caldwell 2015, Ayers et al. 2017). To achieve legitimacy, the state government must develop participatory spaces where constructive deliberation is not dominated by powerful stakeholder groups, particularly because Hawai' $i$ has a multicultural population and a diversity of cultures and worldviews that may already complicate agreements and policy-making (Umemoto 2001, Fung and Wright 2003).

Deliberative democracy approaches offer a suite of participatory design alternatives that may increase legitimacy, equity, and even enhance outcomes. No two public policies, management regimes, or social-ecological systems are the same, so why employ a onesize-fits-all participatory strategy? Varying participant involvement, the type of input and decision making allowed, and the extent of stakeholder's influence on the outcome may promote more fair and efficient outcomes (Fung 2006). For example, if a rural community is pursuing a comanagement area, perhaps commercial fishing or tour businesses situated on other islands should not be considered stakeholders and would be prohibited from participating in and dominating the public input process. Through a restriction like this, it is possible that more limited public participation could lead to a more legitimate and equitable public rulemaking process. However, limiting or creating tiers for consideration of levels of public input in Hawai $i$ and other developed nations would likely require constitutional-level changes. Finally, our analysis suggests that while comanagement can be considered a rights-based approach, communities working toward implementing shared management in Hawai' $i$ were focused on responsibilities such as protecting spawning times, harvesting with restraint, sharing to feed others, and perpetuating knowledge and customary fishing practices (Montgomery and Vaughan 2018, Vaughan 2018). A sense of kuleana, or responsibility to make decisions to ensure healthy resources for future generations, was a key source of legitimacy underpinning community efforts, which has helped communities to endure decades of setbacks. 


\section{CONCLUSION}

Rights-based approaches to small-scale fisheries management such as comanagement are increasingly gaining traction around the world. Although many scholars view rights-based institutional arrangements through the lens of catch shares in commercial fisheries, our analysis of property rights components in Hawai'i coral reef fisheries demonstrates how incentives for stewardship may be conferred along with management rights. Our analysis also demonstrates problems that can arise in comanagement when rights are only partially devolved or when hierarchical decision-making institutions effectively limit opportunities for expansion of comanagement areas.

The level of administrative complexity in coral reef management has remained largely constant in Hawai' $i$, yet property rights in coral reef fisheries management have changed dramatically. Rights once held by local resource managers currently reside with the central government of the State of Hawai' $i$, which devolves only partial management authority to local communities. Existing meta-constitutional- and constitutional-level rules may currently constrain possibilities for rights-based approaches to comanagement in Hawai'i. However, our research offers possibilities that may be applied both locally in Hawai' $i$ and in other places facing similar implementation challenges. Our analysis has also shown how the IAD framework can pinpoint alternative pathways through changes at specific decision-making arenas, the level of administrative complexity necessary to address social-ecological complexity, the role that history and context play in effective institutional design, and how restricting public participation could lead to more legitimate effective community participation in comanagement planning. Targeted stakeholder engagement and negotiation may reduce disputes and conflict that can occur later on in comanagement processes. If the current trend of rights-based approaches in small-scale fisheries continues, these strategies may offer paths toward more effective and legitimate governance transformations.

Responses to this article can be read online at: http://www.ecologyandsociety.org/issues/responses. $\mathrm{php} / 10124$

\section{Acknowledgments:}

We thank the Vaughan lab group, whose comments helped improve an earlier draft of the manuscript. We also thank two anonymous reviewers for their helpful comments through the review process.

\section{LITERATURE CITED}

Acheson, J. M. 2003. Capturing the commons: devising institutions to manage the Maine lobster industry. University Press of New England, Lebanon, New Hampshire, USA.

Acheson, J. M. 2006. Institutional failure in resource management. Annual Review of Anthropology 35:117-134. http:// dx.doi.org/10.1146/annurev.anthro.35.081705.123238

Agranoff, R., and B. A. Radin. 1991. The comparative case study approach in public administration. Research in Public Administration 1:203-231.
Akutagawa, M. 2016. Appendix G: Evaluation of proposed Hawai'i noncommercial marine fishing registry, permit, and license design scenarios and policy recommendations for resolving potential conflicts with native Hawaiian rights. Pages 1-7 in Feasibility of a non-commercial fishing registry, permit, or license system in Hawaiti. Study Group Final Report. Conservation International Hawai $i$, Honolulu, Hawai $i$, USA. [online] URL: http://dlnr.hawaii.gov/dar/announcements/feasibilityof-a-non-commercial-marine-fishing-registry-permit-or-license-systemin-hawaii/

Akutagawa, M., H. Williams, S. Kamaka'ala, and Native Hawaiian Rights Clinic. 2016. Traditional and customary practices report for Mana'e, Moloka i: traditional subsistence uses, Mālama practices and recommendations, and native Hawaiian rights protections of Kama'āina families of Mana'e Moku, East Moloka'i, Hawai $i$. Report prepared for Office of Hawaiian Affairs. William S. Richardson School of Law, University of Hawai'i at Manoa, Honolulu, Hawai'i, USA.

Ayers, A. L., and J. N. Kittinger. 2014. Emergence of comanagement governance for Hawai i coral reef fisheries. Global Environmental Change 28:251-262. http://dx.doi.org/10.1016/j. gloenvcha.2014.07.006

Ayers, A. L., J. N. Kittinger, M. T. Imperial, and M. B. Vaughan. 2017. Making the transition to co-management governance arrangements in Hawai i: a framework for understanding transaction and transformation costs. International Journal of the Commons 11(1):388-421. http://dx.doi.org/10.18352/ijc. 709

Baggio, J. A., A. J. Barnett, I. Perez-Ibarra, U. Brady, E. Ratajczyk, N. Rollins, C. Rubiños, H. C. Shin, D. J. Yu, R. Aggarwal, J. M. Anderies, and M. A. Janssen. 2016. Explaining success and failure in the commons: the configural nature of Ostrom's institutional design principles. International Journal of the Commons 10(2):417-439. http://dx.doi.org/10.18352/ijc.634

Baland, J.-M., and J.-P. Platteau. 1996. Halting degradation of natural resources: Is there a role for rural communities? Food and Agriculture Organization, Rome, Italy. http://dx.doi. org/10.1093/0198290616.001.0001

Baumgartner, F. R., and B. D. Jones. 2009. Agendas and instability in American politics. Second edition. University of Chicago Press, Chicago, Illinois, USA.

Beamer, K. 2014. No Mākou ka Mana: liberating the nation. Kamehameha Publishing, Honolulu, Hawai i, USA.

Berkes, F. 2010. Devolution of environment and resources governance: trends and future. Environmental Conservation 37 (4):489-500. http://dx.doi.org/10.1017/S037689291000072X

Blasiak, R., and C. C. C. Wabnitz. 2018. Aligning fisheries aid with international development targets and goals. Marine Policy 88:86-92. http://dx.doi.org/10.1016/j.marpol.2017.11.018

Boettke, P. J., C. J. Coyne, and P. T. Leeson. 2008. Institutional stickiness and the new development economics. American Journal of Economics and Sociology 67:331-358. https://doi.org/10.1111/ j.1536-7150.2008.00573.x

Bromley, D. W. 1991. Environment and economy: property rights and public policy. Blackwell, Cambridge, Massachusetts, USA. 
Capistrano, R. C. G., and A. T. Charles. 2012. Indigenous rights and coastal fisheries: a framework of livelihoods, rights and equity. Ocean and Coastal Management 69:200-209. http://dx.doi. org/10.1016/j.ocecoaman.2012.08.011

Carothers, C. 2011. Equity and access to fishing rights: exploring the community quota program in the Gulf of Alaska. Human Organization 70(3):213-223. http://dx.doi.org/10.17730/humo.70.3. d686u2r7j2267055

Chock, J. M. 1995. One hundred years of illegitimacy: international legal analysis of the illegal overthrow of the Hawaiian monarchy, Hawai'i's annexation, and possible reparations. University of Hawaii Law Review 17:463-512.

Cinner, J. E., T. R. McClanahan, M. A. MacNeil, N. A. J. Graham, T. M. Daw, A. Mukminin, D. A. Feary, A. L. Rabearisoa, A. Wamukota, N. Jiddawi, S. J. Campbell, A. H. Baird, F. A. Januchowski-Hartley, S. Hamed, R. Lahari, T. Morove, and J. Kuange. 2012. Comanagement of coral reef social-ecological systems. Proceedings of the National Academy of Sciences 109 (14):5219-5222. http://dx.doi.org/10.1073/pnas.1121215109

Community Members of Hā‘ena, Hui Makaāinana o Makana, Limahuli Garden and Preserve, and Hawai i Community Stewardship Network. 2011. Proposed management plan and fishing regulations for the Hā'ena community-based subsistence fishing area. Hā'ena Fisheries Committee, Kaua 'i, Hawaìi, USA.

Costello, C., S. D. Gaines, and J. Lynham. 2008. Can catch shares prevent fisheries collapse? Science 321(5896):1678-1681. http:// dx.doi.org/10.1126/science. 1159478

Cox, M., G. Arnold, and S. V. Tomás. 2010. A review of design principles for community-based natural resource management. Ecology and Society 15(4):38. http://dx.doi.org/10.5751/ ES-03704-150438

Cramer, C. 2010. The Konohiki days of Maunalua Bay. Lawai a Magazine 4:46-49.

Crawford, S. E. S., and E. Ostrom. 1995. A grammar of institutions. American Political Science Review 89(3):582-600. http://dx.doi.org/10.2307/2082975

Davis, A., and S. Jentoft. 2001. The challenge and the promise of indigenous peoples' fishing rights - from dependency to agency. Marine Policy 25(3):223-237. http://dx.doi.org/10.1016/S0308-597X (01)00014-8

Davis, C. 2014. Fishing feud off Molokai leads to arrests and indictments. News Now10 December 2014. [online] URL: $\underline{\text { http:// }}$ www.hawaiinewsnow.com/story/27591608/fishing-feud-off-molokaileads-to-arrests-and-indictments

Diver, S. 2012. Columbia River tribal fisheries: life history stages of a co-management institution. Page 207-236 in B. J. Colombi and J. Brooks, editors. Keystone nations: indigenous peoples and salmon across the north Pacific. School for Advanced Research Press, Santa Fe, New Mexico, USA.

Division of Aquatic Resources. 2016. Draft: Management plan for the Hā'ena community-based subsistence fishing area, Kaua'i. Division of Aquatic Resources, Honolulu, Hawai i, USA. [online] URL: http://dlnr.hawaii.gov/dar/files/2016/03/Haena CBSFA Draft_Mgmt Plan 3.1.16.pdf
Dye, T., and E. Komori. 1992. A pre-censal population history of Hawai 'i. New Zealand Journal of Archaeology 14:113-128. [online] URL: https://nzarchaeology.org/download/pre-censal-populationhistory-of-hawaii? wpdmdl $=3907 \&$ ind $=0$

Finkbeiner, E. M., A. L. Ayers, J. N. Kittinger, and L. B. Crowder. 2015. A comparison of small-scale fisheries governability: Baja California Sur, Mexico and the Hawaiian Islands. Pages 199-221 in S. Jentoft and R. Chuenpagdee, editors. Interactive governance for small-scale fisheries: global reflections. Springer, Cham, Switzerland. http://dx.doi.org/10.1007/978-3-319-17034-3 11

Food and Agriculture Organization. 2016. The state of world fisheries and aquaculture 2016: contributing to food security and nutrition for all. Food and Agriculture Organization, Rome, Italy. [online] URL: http://www.fao.org/documents/card/en/ c/2c8bcf47-2214-4aeb-95b0-62ddef8a982a/

Forman, D. M., and S. K. Serrano. 2012. Ho'ohana Aku, a Ho`ōla Aku: a legal primer for traditional and customary rights in Hawai $i$. Office of Hawaiian Affairs, Honolulu, Hawai i, USA. [online] URL: https://www.law.hawaii.edu/sites/www.law.hawaii.edu/files/ content/Programs $\% 2$ CClinics $\% 2$ CInstitutes/Ho $\% 27$ ohana $\% 20 \mathrm{Aku} \%$ 20Final.pdf

Friedlander, A. M., and E. E. DeMartini. 2002. Contrasts in density, size, and biomass of reef fishes between the northwestern and the main Hawaiian islands: the effects of fishing down apex predators. Marine Ecology Progress Series 230:253-264. http://dx. doi.org/10.3354/meps230253

Friedlander, A. M., and J. D. Parrish. 1998. Habitat characteristics affecting fish assemblages on a Hawaiian coral reef. Journal of Experimental Marine Biology and Ecology 224(1):1-30. http://dx. doi.org/10.1016/S0022-0981(97)00164-0

Friedlander, A. M., J. M. Shackeroff, and J. N. Kittinger. 2013. Customary marine resource knowledge and use in contemporary Hawai' i. Pacific Science 67(3):441-460. http://dx.doi.org/10.2984/67.3.10

Fung, A. 2006. Varieties of participation in complex governance. Public Administration Review 66(S1):66-75. http://dx.doi. org/10.1111/j.1540-6210.2006.00667.x

Fung, A., and E. O. Wright. 2003. Deepening democracy: institutional innovations in empowered participatory governance. Verso, London, UK.

Gelcich, S., G. Edwards-Jones, M. J. Kaiser, and J. C. Castilla. 2006. Co-management policy can reduce resilience in traditionally managed marine ecosystems. Ecosystems 9 (6):951-966. http://dx.doi.org/10.1007/s10021-005-0007-8

Gelcich, S., T. P. Hughes, P. Olsson, C. Folke, O. Defeo, M. Fernández, S. Foale, L. H. Gunderson, C. Rodríguez-Sickert, M. Scheffer, R. S. Steneck, and J. C. Castilla. 2010. Navigating transformations in governance of Chilean marine coastal resources. Proceedings of the National Academy of Sciences 107 (39):16794-16799. http://dx.doi.org/10.1073/pnas.1012021107

Gelcich, S., M. J. Kaiser, J. C. Castilla, and G. Edwards-Jones. 2008. Engagement in co-management of marine benthic resources influences environmental perceptions of artisanal fishers. Environmental Conservation 35(1):36-45. http://dx.doi. org/10.1017/S0376892908004475 
Giliberti-Ippel, A. 2016. Big Island's new marine reserve was a long time coming. Honolulu Civil Beat 6 June 2016. [online] URL: http://www.civilbeat.org/2016/06/big-islands-new-marine-reservewas-a-long-time-coming/

Ginter, J. J. C. 1995. The Alaska community development quota fisheries management program. Ocean and Coastal Management 28(1-3):147-163. http://dx.doi.org/10.1016/0964-5691(95)00069-0

Gonschor, L., and K. Beamer. 2014. Toward an inventory of ahupua'a in the Hawaiian Kingdom: a survey of nineteenth- and early twentieth-century cartographic and archival records of the Island of Hawai'i. Hawaiian Journal of History 48:53-87. [online] URL: http://hdl.handle.net/10524/47256

Grafeld, S., K. L. L. Oleson, L. Teneva, and J. N. Kittinger. 2017. Follow that fish: uncovering the hidden blue economy in coral reef fisheries. Plos One 12(8):e0182104. http://dx.doi.org/10.1371/ journal.pone. 0182104

Grafton, R. Q., R. Arnason, T. Bjørndal, D. Campbell, H. F. Campbell, C. W. Clark, R. Connor, D. P. Dupont, R. Hannesson, R. Hilborn, J. E. Kirkley, T. Kompas, D. E. Lane, G. R. Munro, S. Pascoe, D. Squires, S. I. Steinshamn, B. R. Turris, and Q. Weninger. 2006. Incentive-based approaches to sustainable fisheries. Canadian Journal of Fisheries and Aquatic Sciences 63 (3):699-710. http://dx.doi.org/10.1139/f05-247

Guth, H. K. 1999. Moloka'i group awaits decision from BLNR on subsistence fishing zone. Environment Hawaii February 1999. [online] URL: http://www.environment-hawaii.org/?p=3319

Gutiérrez, N. L., R. Hilborn, and O. Defeo. 2011. Leadership, social capital and incentives promote successful fisheries. Nature 470(7334):386-389. http://dx.doi.org/10.1038/nature09689

Handy, E. S. C., and M. K. Pūkui. 1950. The Polynesian family system in Ka-'u, Hawai'i. Journal of the Polynesian Society 59:232-240. [online] URL: http://www.jps.auckland.ac.nz/ document/Volume 59 1950/Volume 59\%2C No. $3 /$

The Polynesian_family system_in_Ka- $\% 26 \% 2339 \% 3 \mathrm{Bu} \% 2 \mathrm{C} \_$Hawaii $\%$ $\underline{2 \mathrm{C}}$ by E. S. C. Handy $\% 2 \mathrm{C}$ p 232-240/p1?action=null

Higuchi, J. 2008. Propogating cultural kippuka: the obstacles and opportunities of establishing a community-based subsistence fishing area. University of Hawaii Law Review 31:193-224.

Howlett, M., and J. Rayner. 2006. Understanding the historical turn in the policy sciences: a critique of stochastic, narrative, path dependency and process-sequencing models of policy-making over time. Policy Sciences 39:1. http://dx.doi.org/10.1007/ $\underline{\text { s11077-005-9004-1 }}$

Hui Malama o Mo'omomi. 1995. Proposal to designate Mo'omomi community-based subistence fishing area, northwest coast of Moloka i. Department of Land and Natural Resources, Honolulu, Hawai i, USA.

'İ'ī, J. P. 1993. Fragments of Hawaiian history. Second revised edition. Bishop Museum Press, Honolulu, Hawai i.

Imperial, M. T. 1999. Institutional analysis and ecosystem-based management: the institutional analysis and development framework. Environmental Management 24(4):449-465. http://dx. doi.org/10.1007/s002679900246
Imperial, M. T., and T. Yandle. 2005. Taking institutions seriously: using the IAD framework to analyze fisheries policy. Society and Natural Resources 18(6):493-509. http://dx.doi. org/10.1080/08941920590947922

Jentoft, S. 1989. Fisheries co-management: delegating government responsibility to fishermen's organizations. Marine Policy 13(2):137-154. http://dx.doi.org/10.1016/0308-597X(89) 90004-3

Jentoft, S. 2000. Legitimacy and disappointment in fisheries management. Marine Policy 24(2):141-148. http://dx.doi. org/10.1016/S0308-597X(99)00025-1

Johannes, R. E. 2002. The rennaissance of community-based marine resource management in Oceania. Annual Review of Ecology and Systematics 33:317-340. https://doi.org/10.1146/ annurev.ecolsys.33.010802.150524

Jokiel, P. L., K. S. Rodgers, W. J. Walsh, D. A. Polhemus, and T. A. Wilhelm. 2011. Marine resource management in the Hawaiian Archipelago: the traditional Hawaiian system in relation to the Western approach. Journal of Marine Biology 2011:151682. http:// dx.doi.org/10.1155/2011/151682

Kahā'ulelio, D. 2006. Ka 'Oihana Lawai 'a: Hawaiian fishing traditions. Translated by Mary Kawena Pūkui. Bishop Museum Press and Awaiaulu Press, Honolulu, Hawai i, USA.

Kamakau, S. M. 1976. The works of the people of old: Na Hana a ka Po'e Kahiko. Bishop Museum Press, Honolulu, Hawai'i, USA.

Kame'eleihiwa, L. 1992. Native land and foreign desires: Pehea lā e pono ai? How shall we live in harmony? Bishop Museum Press, Honolulu, Hawaii, USA.

Kasperski, S., and D. S. Holland. 2013. Income diversification and risk for fishermen. Proceedings of the National Academy of Sciences 110(6):2076-2081. http://dx.doi.org/10.1073/pnas.1212278110

Kirch, P. V. 1990. Monumental architecture and power in Polynesian chiefdoms: a comparison of Tonga and Hawaii. World Archaeology 22(2):206-222. http://dx.doi.org/10.1080/00438243.1990.9980141

Kirch, P. V. 2007. "Like shoals of fish": archaeology and population in pre-contact Hawai'i. Pages 69-52in P. V. Kirch and J.-L. Rallu, editors. The growth and collapse of Pacific Island societies: archaeological and demographic perspectives. University of Hawai i Press, Honolulu, Hawaii, USA.

Kirch, P. V. 2010. How Chiefs became Kings: divine Kingship and the rise of archaic states in ancient Hawai $i$. University of California Press, Berkeley, California, USA.

Kirch, P. V., and M. Sahlins. 1994. Anahulu: the anthropology of history in the Kingdom of Hawaii. Volume 1: historical ethnography. University of Chicago Press, Chicago, Illinois, USA.

Kiser, L. L., and E. Ostrom. 1982. The three worlds of action: a metatheoretical synthesis of institutional approaches. Pages 179-222 in E. Ostrom, editor. Strategies of political inquiry. Sage, Thousand Oaks, California, USA. 
Kiser, L. L., and E. Ostrom. 2000. The three worlds of action: a metatheoretical synthesis of institutional approaches. Pages 56-88 in M. D. McGinnis, editor. Polycentric games and institutions: readings from the Workshop in Political Theory and Policy Analysis. University of Michigan Press, Ann Arbor, Michigan, USA.

Kittinger, J. N. 2010. Historical ecology of coral reefs in the Hawaiian Archipelago. Dissertation. University of Hawaii at Manoa, Honolulu, Hawaii, USA.

Kittinger, J. N., A. L. Ayers, and E. Prahler. 2012. Policy briefing: co-management of coastal fisheries in Hawaii: overview and prospects for implementation. Conservation International Hawaii, Honolulu, Hawaii, USA. http://dx.doi.org/10.2139/ssrn.2590207

Kittinger, J. N., J. M. Pandolfi, J. H. Blodgett, T. L. Hunt, H. Jiang, K. Maly, L. E. McClenachan, J. K. Schultz, and B. A. Wilcox. 2011. Historical reconstruction reveals recovery in Hawaiian coral reefs. Plos One 6(10):e25460. http://dx.doi. org/10.1371/journal.pone.0025460

Kittinger, J. N., L. T. Teneva, H. Koike, K. A. Stamoulis, D. S. Kittinger, K. L. L. Oleson, E. Conklin, M. Gomes, B. Wilcox, and A. M. Friedlander. 2015. From reef to table: social and ecological factors affecting coral reef fisheries, artisanal seafood supply chains, and seafood security. Plos One 10(8):e0123856. http://dx.doi.org/10.1371/journal.pone.0123856

Kosaki, R. H. 1954. Konohiki fishing rights. Legislative Reference Bureau, University of Hawaii, Honolulu, Hawaii, USA. [online] URL: http://1rbhawaii.info/lrbrpts/54/konohiki.pdf

Levine, A. S., and L. S. Richmond. 2014. Examining enabling conditions for community-based fisheries comanagement: comparing efforts in Hawai'i and American Samoa. Ecology and Society 19(1):24. http://dx.doi.org/10.5751/ES-06191-190124

Lewis, G. H. 1987. Style in revolt music, social protest, and the Hawaiian cultural renaissance. International Social Science Review 62(4):168-177. [online] URL: http://www.jstor.org/ $\underline{\text { stable/41881768 }}$

Liebowitz, S. J., and S. E. Margolis. 1995. Path dependence, lockin, and history. Journal of Law, Economics and Organization 11 (1):205-226. http://dx.doi.org/10.2139/ssrn.1706450

MacKenzie, M. K., editor. 1991. Native Hawaiian rights handbook. Native Hawaiian Legal Corporation and Office of Hawaiian Affairs, Honolulu, Hawaii, USA. [online] URL: http:// nhlchi.org/images/uploads/Native Hawaiian Rights Handbook. pdf

MacNeil, A. M., and J. E. Cinner. 2013. Hierarchical livelihood outcomes among co-managed fisheries. Global Environmental Change 23(6):1393-1401. https://doi.org/10.1016/j.gloenvcha.2013.04.003

Malo, D. 1951. Hawaiian antiquities: mo'olelo Hawai i. Bishop Museum Press, Honolulu, Hawaii, USA.

Maly, K., and O. Maly. 2003. "Hana ka lima, "ai ka waha”: a collection of historical accounts and oral history interviews with Kama'àina residents and fisher-people of lands in the Halele'anāpali region on the island of Kaua i $i$. Kumu Pono Associates, Hilo, Hawaii, USA. [online] URL: http://kumupono.com/KPA $\%$ 20Study $\% 20$ Intros/Haena $\% 20 \& \% 20$ Vicinity $\% 20$ Kauai $\% 20$ (KPA $\%$ 20HiPae74\%20Halelea-Napali $\% 20111003$ ).pdf
Matsuoka, J. K., D. McGregor, and L. Minerbi. 1994. Governor's Moloka i Subsistence Task Force final report. Department of Business, Economic Development and Tourism, Honolulu, Hawaii, USA.

Maurin, P., and S. Peck. 2008. The West Hawai i Fisheries Council case study report. University of Hawaii Sea Grant College Program, University of Hawaii, Honolulu, Hawaii, USA. [online] URL: http://seagrant.soest.hawaii.edu/west-hawaii-fisheries-councilcase-study-report

McClenachan, L., and J. N. Kittinger. 2013. Multicentury trends and the sustainability of coral reef fisheries in Hawai' $i$ and Florida. Fish and Fisheries 14:239-255. https://doi.org/10.1111/ j.1467-2979.2012.00465.X

McGinnis, M. D. 2011. An introduction to IAD and the language of the Ostrom Workshop: a simple guide to a complex framework. Policy Studies Journal 39(1):169-183. http://dx.doi.org/10.1111/ j.1541-0072.2010.00401.X

McGinnis, M. D., and E. Ostrom. 2014. Social-ecological system framework: initial changes and continuing challenges. Ecology and Society 19(2):30. http://dx.doi.org/10.5751/ES-06387-190230

McGregor, D. P. 1996. An introduction to the Hoa āina and their rights. Hawaiian Journal of History 30:1-27. [online] URL: http:// hdl.handle.net/10524/251

McGregor, D. P. 2007. Nā Kua‘āina: living Hawaiian culture. University of Hawaii Press, Honolulu, Hawaii, USA.

Miles, M. B., and A. M. Huberman. 1994. Qualitative data analysis: an expanded sourcebook. Second edition. Sage, Thousand Oaks, California, USA.

Montgomery, M., and M. Vaughan. 2018. Kippuka Kuleana: restoring reciprocity to coastal land tenure and resource use in Hawai'i. In N. Turner, editor. Plants, people and places: the roles of ethnobotany and ethnoecology in indigenous peoples' land rights in Canada and beyond. McGill-Queen's University Press, Montreal, Canada. In press.

Murakami, A. T., and W. C. Tanaka. 2015. Konohiki fishing rights. Chapter 10 in M. K. MacKenzie, editor. Native Hawaiian law: a treatise. Kamehameha Publishing, Honolulu, Hawai'i, USA.

Nadasdy, P. 2003. Reevaluating the co-management success story. Arctic 56(4):367-380. http://dx.doi.org/10.14430/arctic634

Nielsen, J. R. 2003. An analytical framework for studying: compliance and legitimacy in fisheries management. Marine Policy 27(5):425-432. http://dx.doi.org/10.1016/S0308-597X(03) $\underline{00022-8}$

Nordyke, E. C. 1989. The peopling of Hawai i. Second edition. University of Hawaii Press, Honolulu, Hawaii, USA.

Oliveira, K.-A. R. K. N. 2014. Ancestral places: understanding Kanaka geographies. Oregon State University Press, Corvalis, Oregon, USA.

Osorio, J. K. K. 2002. Dismembering Lāhui : a history of the Hawaiian nation to 1887. University of Hawai'i Press, Honolulu, Hawaii, USA. 
Ostrom, E. 1990. Governing the commons: the evolution of institutions for collective action. Cambridge University Press, Cambridge, UK.

Ostrom, E. 1998. Scales, polycentricity, and incentives: designing complexity to govern complexity. Pages 149-167 in L. D. Guruswamy and J. A. McNeely, editors. Protection of global biodiversity: converging strategies. Duke University Press, Durham, North Carolina, USA.

Ostrom, E. 2005. Understanding insitutional diversity. Princeton University Press, Princeton, New Jersey, USA.

Ostrom, E. 2007. A diagnostic approach for going beyond panaceas. Proceedings of the National Academy of Sciences 104 (39):15181-15187. http://dx.doi.org/10.1073/pnas.0702288104

Ostrom, E. 2009. A general framework for analyzing sustainability of social-ecological systems. Science 325 (5939):419-422. http://dx.doi.org/10.1126/science.1172133

Ostrom, E. 2011. Background on the institutional analysis and development framework. Policy Studies Journal 39(1):7-27. http:// dx.doi.org/10.1111/j.1541-0072.2010.00394.X

Ostrom, E., R. Gardner, and J. Walker. 1994. Rules, games, and common-pool resources. University of Michigan Press, Ann Arbor, Michigan, USA. http://dx.doi.org/10.3998/mpub.9739

Ostrom, E., L. Schroeder, and S. Wynne. 1993. Institutional incentives and sustainable development: infrastructure policies in perspective. Westview Press, Boulder, Colorado, USA.

Ostrom, V. 1980. Artisanship and artifact. Public Administration Review 40(4):309-317. http://dx.doi.org/10.2307/3110256

Page, G. G., A. Swanenberg, and T. Maddalene. 2013. An analysis of issues affecting the management of coral reefs and the associated capacity building needs in the main Hawaiian Islands. Page 135. SustainaMetrix, Baltimore, Maryland, USA. [online] URL: https://repository.library.noaa.gov/view/noaa/950

Pinkerton, E., editor. 1989. Cooperative management of local fisheries: new directions for improved management and community development. University of British Columbia Press, Vancouver, Canada.

Pinkerton, E. 1992. Translating legal rights into management practice: overcoming barriers to the exercise of co-management. Human Organization 51(4):330-341. http://dx.doi.org/10.17730/ humo.51.4.v0127327j24u378r

Pinkerton, E. 1999. Factors in overcoming barriers to implementing co-management in British Columbia salmon fisheries. Conservation Ecology 3(2):2. http://dx.doi.org/10.5751/ ES-00150-030202

Poepoe, K., P. K. Bartram, and A. M. Friedlander. 2007. The use of traditional knowledge in the contemporary management of a Hawaiian community's marine resources. Pages 119-143 in N. Haggan, B. Neis, and I. G. Baird, editors. Fisher's knowledge in fisheries science and management. United Nations Educational, Scientific and Cultural Organization, Paris, France. [online] URL: http://unesdoc.unesco.org/images/0015/001505/150580e. $\underline{\mathrm{pdf}}$
Pomeroy, R. S., B. M. Katon, and I. Harkes. 2001. Conditions affecting the success of fisheries co-management: lessons from Asia. Marine Policy 25(3):197-208. http://dx.doi.org/10.1016/ S0308-597X(01)00010-0

Preza, D. C. 2009. The empirical writes back: re-examining Hawaiian dispossession resulting from the Māhele of 1848. Thesis. University of Hawai' i, Honolulu, Hawaii, USA.

Ribot, J. C., and N. L. Peluso. 2003. A theory of access. Rural Sociology 68(2):153-181. http://dx.doi.org/10.1111/j.1549-0831.2003. tb00133.x

Richmond, L., and A. Levine. 2012. Institutional analysis of community-based marine resource management initiatives in Hawai $i$ and American Samoa. NOAA Technical Memorandum NMFS-PIFSC-35. U.S. Department of Commerce, Honolulu, Hawaii, USA. [online] URL: https://www.pifsc.noaa.gov/library/ pubs/tech/NOAA Tech Memo PIFSC 35.pdf

Rosenberg, A. A., K. M. Kleisner, J. Afflerbach, S. C. Anderson, M. Dickey-Collas, A. B. Cooper, M. J. Fogarty, E. A. Fulton, N. L. Gutiérrez, K. J. W. Hyde, E. Jardim, O. P. Jensen, T. Kristiansen, C. Longo, C. V. Minte-Vera, C. Minto, I. Mosqueira, G. C. Osio, D. Ovando, E. R. Selig, J. T. Thorson, J. C. Walsh, and Y. Ye. 2018. Applying a new ensemble approach to estimating stock status of marine fisheries around the world. Conservation Letters 11(1):e12363. http://dx.doi.org/10.1111/conl.12363

Rossiter, J. S., and A. Levine. 2014. What makes a "successful" marine protected area? The unique context of Hawaii's fish replenishment areas. Marine Policy 44:196-203. http://dx.doi. org/10.1016/j.marpol.2013.08.022

Rust, S. 2013. Who owns the fish? Salon 12 March 2013. [online] URL: https://www.salon.com/2013/03/12/who owns the fish/

Sax, J. L. 1969. The public trust doctrine in natural resource law: effective judicial intervention. Michigan Law Review 68 (3):471-566. http://dx.doi.org/10.2307/1287556

Schemmel, E. M., and A. M. Friedlander. 2017. Participatory fishery monitoring is successful for understanding the reproductive biology needed for local fisheries management. Environmental Biology of Fishes 100(2):171-185. http://dx.doi. org/10.1007/s10641-016-0566-X

Schlager, E., and E. Ostrom. 1992. Property-rights regimes and natural resources: a conceptual analysis. Land Economics 68 (3):249-262. http://dx.doi.org/10.2307/3146375

Schlager, E., and E. Ostrom. 1999. Property rights regimes and coastal fisheries: an empirical analysis. Pages 87-113 in M. D. McGinnis, editor. Polycentric governance and development: readings from the Workshop in Political Theory and Policy Analysis. University of Michigan Press, Ann Arbor, Michigan, USA.

Scott, A. 1988. Development of property in the fishery. Marine Resource Economics 5(4):289-311. http://dx.doi.org/10.1086/ mre.5.4.42628932

Sen, S., and J. R. Nielsen. 1996. Fisheries co-management: a comparative analysis. Marine Policy 20(5):405-418. http://dx.doi. org/10.1016/0308-597X(96)00028-0 
Steele, C. H. 2015. He ali i i ka 'āina; he kauwā ke kanaka (The land is Chief; man is its servant): traditional Hawaiian resource stewardship and the transformation of the Konohiki. Thesis. University of Hawaii at Manoa, Honolulu, Hawaii, USA. [online] URL: https://scholarspace.manoa.hawaii.edu/handle/10125/51152

Study Group on the Feasibility of a Non-Commercial Marine Registry, Permit, or License System for Hawai i (Study Group). 2016. Feasibility of a non-commercial fishing registry, permit, or license system in Hawai i. Study Group Final Report. Conservation International Hawai $i$, Honolulu, Hawai i $i$, USA. [online] URL: http://dlnr.hawaii.gov/dar/announcements/feasibilityof-a-non-commercial-marine-fishing-registry-permit-or-license-systemin-hawaii/

Taiepa, T., P. Lyver, P. Horsley, J. Davis, M. Brag, and H. Moller. 1997. Co-management of New Zealand's conservation estate by Maori and Pakeha: a review. Environmental Conservation 24 (3):236-250. http://dx.doi.org/10.1017/S0376892997000325

Teneva, L. T. 2016. State of Hawai i i investment in natural resource management. Conservation International, Arlington, Virginia, USA.

Tissot, B. N., W. J. Walsh, and M. A. Hixon. 2009. Hawaiian Islands marine ecosystem case study: ecosystem- and communitybased management in Hawaii. Coastal Management 37 (3-4):255-273. http://dx.doi.org/10.1080/08920750902851096

Titcomb, M. 1972. Native use of fish in Hawaii. Second edition. University of Hawaii Press, Honolulu, Hawaii, USA.

Umemoto, K. 2001. Walking in another's shoes: epistemological challenges in participatory planning. Journal of Planning Education and Research 21(1):17-31. https://doi.org/10.1177/0739456X0102100102

U.S. Congress. 1897. Joint resolution to provide for annexing the Hawaiian Islands to the United States (1898). U.S. Congress, Washington, D.C., USA. [online] URL: https://www. ourdocuments.gov/doc.php?flash $=$ true $\&$ doc $=54$

Van Dyke, J. M. 2008. Who owns the Crown lands of Hawai $i$ ? University of Hawai'i Press, Honolulu, Hawaii, USA.

Van Dyke, J. M. 2010. What are the 'ceded lands' of Hawaii? Honolulu Civil Beat 25 October 2010. [online] URL: http://www. civilbeat.com/2010/10/5914-what-are-the-ceded-lands-of-hawaii/

Vaughan, M. B. 2018. Kaiāulu: gathering tides. Oregon State University Press, Corvalis, Oregon, USA.

Vaughan, M. B., and A. L. Ayers. 2016. Customary access: sustaining local control of fishing and food on Kaua'i's North shore. Food, Culture and Society 19(3):517-538. http://dx.doi. org/10.1080/15528014.2016.1208339

Vaughan, M. B., and M. R. Caldwell. 2015. Hana pa'a: challenges and lessons for early phases of co-management. Marine Policy 62:51-62. http://dx.doi.org/10.1016/j.marpol.2015.07.005

Vaughan, M. B., B. Thompson, and A. L. Ayers. 2016. Pāwehe ke kai a’o hā'ena: creating state law based on customary indigenous norms of coastal management. Society and Natural Resources 30(1):31-46. https://doi.org/10.1080/08941920.2016.1196406
Vaughan, M. B., and P. M. Vitousek. 2013. Mahele: sustaining communities through small-scale inshore fishery catch and sharing networks. Pacific Science 67(3):329-344. http://dx.doi. org/10.2984/67.3.3

Vaughan, M. D. B. B. 2012. Holoholo i ka Lai o Makua, collaborative community care and management of coastal resources: creating state law based on customary rules to manage a near shore fishery in Hawai i. Dissertation. Stanford University, Stanford, California, USA. [online] URL: https://searchworks. stanford.edu/view/9850495

Vitousek, P. M., T. N. Ladefoged, P. V. Kirch, A. S. Hartshorn, M. W. Graves, S. C. Hotchkiss, S. Tuljapurkar, and O. A. Chadwick. 2004. Soils, agriculture, and society in precontact Hawai' i. Science 304(5677):1665-1669. http://dx.doi.org/10.1126/ science.1099619

Williams, I. D., W. J. Walsh, R. E. Schroeder, A. M. Friedlander, B. L. Richards, and K. A. Stamoulis. 2008. Assessing the importance of fishing impacts on Hawaiian coral reef fish assemblages along regional-scale human population gradients. Environmental Conservation 35(3):261-272. http://dx.doi.org/10.1017/ $\underline{\mathrm{S} 0376892908004876}$

Wilmshurst, J. M., T. L. Hunt, C. P. Lipo, and A. J. Anderson. 2011. High-precision radiocarbon dating shows recent and rapid initial human colonization of East Polynesia. Proceedings of the National Academy of Sciences 108(5):1815-1820. http://dx.doi. org/10.1073/pnas. 1015876108

Wilson, D. C., and B. J. McCay. 1998. How the participants talk about "participation" in mid-Atlantic fisheries management. Ocean and Coastal Management 41(1):41-61. http://dx.doi. org/10.1016/S0964-5691(98)00080-5

Wilson, J. A. 2006. Matching social and ecological systems in complex ocean fisheries. Ecology and Society 11(1):9. http://dx. doi.org/10.5751/ES-01628-110109

Yandle, T. 2003. The challenge of building successful stakeholder organizations: New Zealand's experience in developing a fisheries co-management regime. Marine Policy 27(2):179-192. http://dx. doi.org/10.1016/S0308-597X(02)00071-4

Yandle, T. 2006. Sharing natural resource management responsibility: examining the New Zealand rock lobster comanagement experience. Policy Sciences 39(3):249-278. http://dx. doi.org/10.1007/s11077-006-9023-6

Yandle, T. 2007. Understanding the consequences of property rights mismatches: a case study of New Zealand's marine resources. Ecology and Society 12(2):27. http://dx.doi. org/10.5751/ES-02181-120227

Zanre, E. 2014. Community-based subsistence fishing area designation procedures guide. Pilot version. Hawai'i Department of Land and Natural Resources, Division of Aquatic Resources, Honolulu, Hawai'i, USA. [online] URL: http://dlnr.hawaii.gov/ coralreefs/files/2015/02/CBSFA-Designation-Procedures-Guide v.1. pdf 